\title{
Class CONFLICT IN SECURITIES FRAUD LITIGATION
}

\author{
Richard A. Booth*
}

\begin{abstract}
Although securities fraud class actions are a well-established legal institution, few (if any) such actions in fact meet the requirements of Rule 23 of the Federal Rules of Civil Procedure for certification as a class action. Among other things, Rule 23 requires the court to find that the representative plaintiff will fairly and adequately protect the interests of the class and that a class action is superior to other means of resolving the dispute.

In a typical securities fraud case, the plaintiff class consists of investors who buy the subject stock at a time when the defendant corporation has negative material information that should be publicly disclosed. When the truth comes out, stock price declines, and those who bought during the fraud period sue the corporation for damages equal to the difference between the price they paid and the price at which the stock finally settles. Only buyers have standing to sue in such circumstances. Mere holders have no claim.

The problem is that most buyers are also holders. Most investors are well diversified. More than two-thirds of all stock is held through mutual funds, pension plans, and other institutional investors, who trade mostly for purposes of portfolio balancing. As a result, most of the buyers in the plaintiff class will also be holders as to more shares than the number of shares bought during the fraud period. Because the defendant corporation pays any settlement-further reducing the value of the corporation and its stock price through feedback - most of the plaintiff class will lose more as holders than they gain as buyers. Thus, many members of the plaintiff class would prefer that the action be dismissed. It is therefore impossible for anyone to be an adequate representative of a class composed of both members who support the action and members who oppose the action. Even if a court would permit a plaintiff class to be gerrymandered to include only those buyers who would gain more than they lose, there is no practical way to identify such investors.
\end{abstract}


In addition, it is likely that in most meritorious securities fraud actions, part of the decrease in stock price will come from expenses associated with defending and settling the securities fraud claim and from harm to the reputation of the defendant company resulting in an increase in its cost of capital. But these claims are properly viewed as derivative rather than direct. Accordingly, it is the corporation - and not individual buyers - who should recover for this portion of the damages. Aside from the fact that such claims are derivative in nature and presumably must be litigated as such, a derivative action is clearly superior to a class action because recovery by the corporation from individual wrongdoers-rather than payment by the corporation to buyers - eliminates feedback damages and thus reduces the size of the aggregate claim. Moreover, a derivative action is more efficient in that there is a single plaintiff - the corporationrather than hundreds or thousands of individual buyers.

Finally, policy considerations also militate against certification. Diversified investors are hedged against securities fraud by virtue of being diversified and have no need for a remedy. A diversified investor is just as likely to sell a fraud-affected stock as to buy one. It all comes out in the wash. Thus, the expenses associated with securities fraud class actions are a deadweight loss that serve only to reduce investor return. Because the vast majority of investors are diversified - and because it is irrational for most investors not to diversify - the interests of diversified investors should trump those of any undiversified investors who would favor a class action remedy. Moreover, class actions constitute excessive deterrence, whereas derivative actions provide a response that is proportional to the true harm suffered by investors. Diversified investors are completely protected against any true loss by the prospect of derivative litigation, which also provides an effective deterrent against securities fraud.

In short, when faced with a motion to certify a securities fraud action as a class action, a court should ordinarily treat the action as derivative and proceed accordingly. To be clear, this approach would effectively abolish securities fraud class actions and replace them with derivative actions. But as demonstrated here, investors would be better off as a result. 


\section{INTRODUCTION}

A securities fraud class action under Rule $10 \mathrm{~b}-5$ usually arises from the failure of a publicly traded company to disclose material information in a timely fashion. ${ }^{1}$ The information may be either good news or bad news. Law.

* Martin G. McGuinn Professor of Business Law, Villanova University School of

1. 17 C.F.R. $\S 240.10 b-5$ (2012). The focus here is on securities fraud class actions arising under the Securities Exchange Act of 1934 (and Rule 10b-5 promulgated thereunder) in connection with trading in outstanding shares. Although class actions also arise in connection with initial public offerings (IPOs) — as well as subsequent offerings by publicly traded companies - such claims under the 1933 Act are fundamentally different because they involve the offer and sale of stock by the defendant company. In contrast, claims arising under Rule 10b-5 are based on the purchase or sale of outstanding shares in trading that does not involve the company itself at a time when the market price is allegedly affected by the nondisclosure (cover-up) of material information. Over the last fifteen years (since 1996), more than 2800 securities fraud class actions have been filed against publicly traded companies in the United States. Cornerstone Research, Securities Class Action FILINGS: 2010 YEAR IN REVIEW 3 (2011). These actions have resulted in settlements of about \$64 billion. See Ellen M. Ryan \& Laura E. Simmons, Cornerstone Research, Securities Class Action Settlements: 2010 Review AND ANalysis 1 (2011) [hereinafter 2010 REVIEW AND ANALYSIS], (listing yearly settlement totals from 2001 through 2010); Laura E. Simmons \& Ellen M. Ryan, Cornerstone Research, Post-Reform ACt SECURITIES SETtLEMENTS: 2005 REVIEW AND ANALysis 1 (2006) [hereinafter 2005 RevieW AND ANALYSIS] (listing yearly settlement totals from 1997 through 2005). Selected data from these Cornerstone reports is collected in the appendix hereto.

Most securities fraud class actions arise under Rule 10b-5. During the period 2006 to 2010 , the proportion of securities fraud class actions including Rule $10 \mathrm{~b}-5$ claims ranged from a high of $87 \%$ (in 2006) to a low of $66 \%$ (in 2010) though the trend was distinctly downward. Cornerstone Research, Securities Class Action Filings: 2010 Year in REVIEW at 32. The significance of the distinction between Rule 10b-5 claims and 1933 Act claims is discussed further below. The standard practice is to pay plaintiff attorney fees and other expenses out of the award. On average, a rough but conservative estimate is that about $20 \%$ of a settlement goes to plaintiff attorney fees and expenses. See Anjan V. Thakor, Navigant Consulting, The Economic Reality of Securities Class Action Litigation Exhibit A-1 (2005) (finding plaintiff attorney fees of $\$ 3.1$ billion in connection with settlements totaling $\$ 19.8$ billion in a sample of 482 class actions or about $16 \%$ of the settlement amounts); Denise M. Martin, et al., Recent Trends IV: What Explains Filings and Settlements in Shareholder Class Actions, 5 STAN. J.L. Bus. \& Fin. 121, 141 (1999) (finding average fees of 32\%); Theodore Eisenberg \& Geoffrey Miller, Attorney's Fees and Expenses in Class Action Settlements: 1993-2008 (NYU School of Law, Law and Economics Working Paper 09-50) (Nov. 2009) (finding average fees of 23\%). Thus, it would appear that plaintiff attorney fees and expenses have totaled about $\$ 13$ billion since 1996. Assuming that defendant law firms have been paid roughly the same amount, it seems a fair estimate that securities fraud class actions have generated about $\$ 26$ billion in attorney fees over the last ten years. To be sure, defendant firms are paid in all cases, whether or not the plaintiff prevails, but presumably defendant firm fees are a good deal less than plaintiff firm fees in cases in which plaintiffs prevail. Plaintiffs succeed to some extent in about $40 \%$ of cases. See Appendix (collecting Cornerstone data). Awards are usually paid by defendant company's insurance. See Tom Baker \& Sean Griffith, Predicting 
In other words, an action may be triggered by news that causes the price of a stock to rise - in which case those who sold during the fraud period suffer harm-or by news that causes the price of a stock to fall-in which case those who bought during the fraud period suffer harm. There are notable examples of both types of fraud. ${ }^{2}$ But actions based on bad news are far more common. ${ }^{3}$ Thus, the discussion here generally assumes that the fraud involves a failure to disclose bad news.

In a bad news case, the plaintiff class consists of all who purchased the stock in question during the fraud period and continue to hold it until corrective disclosure. ${ }^{4}$ The standard approach to damages in a bad news

Corporate Governance Risk: Evidence from the Directors' \& Officers' Liability Insurance Market, 74 U. CHI. L. REV. 487, 488 (2007) (explaining that shareholder litigation, including class actions, usually settle within the limits of the corporations' insurance coverage).

2. See, e.g., Stoneridge Inv. Partners, L.L.C. v. Scientific-Atlanta, Inc., 552 U.S. 148 (2008) (bad news); Dura Pharm., Inc. v. Broudo, 544 U.S. 336 (2005) (bad news); Basic, Inc. v. Levinson, 485 U.S. 224 (1988) (good news); In re Time Warner Inc. Sec. Litig., 9 F.3d 259 (2d Cir. 1993) (bad news); Sec. and Exch. Comm'n v. Tex. Gulf Sulphur Co., 401 F.2d 833 (2d Cir. 1968) (good news). There are, of course, many other forms of securities fraud, ranging from those arising in face-to-face dealings to those arising in connection with corporate level mismanagement, but these other actions are seldom amenable to pursuit as class actions. In other words, securities fraud class actions almost invariably arise because of an issuer's failure to disclose material information to the market in a timely fashion.

3. Actions based on bad news are more common because of the way damages are awarded in securities fraud class actions. Because the company pays, the stock price falls further thus enhancing damages through positive feedback and making the securities fraud class action that much more lucrative for the plaintiff lawyers. In a good news case, the securities fraud class action has the effect of muting the price increase through negative feedback and reducing the potential award. For example, data indicate that of the 119 securities fraud class actions filed in 2006, only two involved good news. Author Analysis of Stanford University Securities Class Action Clearinghouse (SCAC) 2006 data (on file with author).

4. The fraud period is the period between an actionable misrepresentation or omission and corrective disclosure. Some may quibble with this characterization in that it can be unclear exactly when the truth comes out. See Broudo v. Dura Pharm., Inc., 339 F.3d 933, 938 (9th Cir. 2003) (holding that an inflated purchase price was enough to show loss causation, even though the price did not fall with corrective disclosure), rev'd, 544 U.S. 336, 338 (2005) (holding that loss causation is proved by evidence that investors suffered a loss caused by purchasing a stock that was overpriced as a result of false statements or omissions). See also Jay W. Eisenhofer, Geoffrey C. Jarvis \& James R. Banko, Securities Fraud, Stock Price Valuation, and Loss Causation: Toward a Corporate Finance-Based Theory of Loss Causation, 59 Bus. LAw. 1419, 1419-21 (2004) (arguing that a stock price decline corresponding with disclosure should not be necessary to sustain a fraud claim). Nevertheless, no one seems to deny that the price of the stock must decline for some reason after the plaintiff purchases, and most would likely agree that the decline must somehow be tied to the original failure to disclose. See Dura Pharm., Inc., 544 U.S. at 343 (2005) (holding that the inflated purchase price itself does not constitute a claim); Emergent Capital Inv. Mgmt., LLC v. Stonepath Grp., Inc., 343 F.3d 189, 198-99 (2d Cir. 2003) (plaintiffs must allege price correction to plead loss causation). Thus, for convenience, I will assume here that a prototypical securities fraud class action involves a prolonged failure of disclosure followed by a corrective disclosure by which the whole truth comes out all at 
case is to award the difference between the price paid by the buyer and the market price after corrective disclosure. ${ }^{5}$ And it is the company (or its insurer) that pays the award. ${ }^{6}$ But the investor who innocently sells an overpriced stock need not disgorge her (effective) gain.

Although one might think that investors are protected by securities fraud class actions and thus would favor them as a legal institution, one would be wrong. Most investors are diversified. From the viewpoint of diversified investors - the great majority of investors - class actions confer

once and with no interim leakage. I should note that I do not distinguish here between misrepresentations and omissions. Both are generally actionable, although there are subtle differences in the relevant law. Compare Affiliated Ute Citizens of Utah v. United States, 406 U.S. 128 (1972) (finding a 10b-5 violation where bank employees induced owners of a development corporation to sell their stock while omitting facts which would have been likely to influence their decisions whether to sell), with Basic, Inc., 485 U.S. at 249 (finding a 10b-5 violation where the company misrepresented to the public that it was not involved in merger talks, when in fact merger talks were ongoing). In practice, most securities fraud class actions arise from some combination of the two. For example, a company might issue a press release or periodic report that is correct at the time of release. The press release then becomes false or misleading as a result of intervening events, but the company then fails to issue another release to correct the lingering false impression. See In re Time Warner Sec. Litig., 9 F.3d 259, 270 (N.Y. 1993) (statements accurate when made, but later require correction so as not to mislead the market).

5. This description of how damages are calculated is a bit oversimplified, but it is good enough for present purposes. Although there has been no case in which a jury has actually done so, the courts generally have agreed that the jury should determine the correct market price of the subject stock on each day during the fraud period, in effect creating a price line that would be compared to the daily market price to determine the damages for investors who bought on any given day. This approach to calculating damages can be traced back to Green v. Occidental Petroleum Corp., 541 F.2d 1335 (9th Cir. 1976), and it is the formulation upon which Congress relied in connection with the Private Securities Litigation Reform Act (PSLRA). See H.R. REP. No. 104-369, at 42 (1995) (Conf. Rep.) (In calculating damages, provides for the taking into account of the date which a plaintiff purchased the security). Although this is a common description of the measure of damages, and may well be applied in some cases, it is a gross oversimplification. For example, factors other than fraud may have affected market price before corrective disclosure. Or the truth may dribble out. See Janet Cooper Alexander, Rethinking Damages in Securities Class Actions, 48 STAN. L. REV. 1487, 1490-92 (1996) (describing the difficulty in calculating the effect of withheld information on the market price); Richard A. Booth, Windfall Awards Under PSLRA, 59 BUS. LAW. 1043, 1047-54 (2004) (discussing effect of truth leaking out); Michael Y. Scudder, Comment, The Implications of Market-Based Damages Caps in Securities Class Actions, 92 Nw. U. L. REV. 435, 462 (1997) (explaining how extraneous events can also affect the market price). Of course, most securities fraud class actions are settled if they are not dismissed. Thus, it is unusual for damages ever to be awarded by a court. Nevertheless, the putative measure of damages will affect settlement negotiations. Moreover, given that the settlement of a class action must be approved by the court, the court itself may well consider the parties' assumptions and estimates as to damages. Accordingly, I use the more neutral word award to refer herein to both damages and settlements.

6. See Baker \& Griffith, supra note 1, at 533 (describing the insurers' substantial role in shareholder litigation). 
no genuine benefit because a diversified investor is equally likely to sell an overpriced stock (and gain) as to buy one (and lose). So gains and losses wash out. In other words, a diversified investor is effectively insured against securities fraud. For a diversified investor, the cost of class actions - in attorney fees and other expenses - constitutes a deadweight loss, like buying a second insurance policy when one can recover only once. At best, recovery via class action is an expensive rearrangement of wealth from one pocket to another-minus a cut for the lawyers.

Diversified investors lose even more from securities fraud class actions in cases in which they are mere holders of the subject stock. Only buyers have standing to sue for their losses under Rule 10b-5. ${ }^{7}$ But the prospect of payout by the defendant company causes its stock price to fall more than it otherwise would. Moreover, it triggers a positive feedback mechanism that has the effect of magnifying the potential payout. In other words, the prospect of payout to the plaintiff class causes the price of the subject stock to fall by an amount in addition to the decrease attributable to the disclosure of new negative information. That in turn increases the potential damages payable by the subject company causing a further decrease in price. And so on. ${ }^{8}$ The bottom line is that class actions reduce

7. See Merrill Lynch, Pierce, Fenner \& Smith, Inc. v. Dabit, 547 U.S. 71, 87 (2006) (holding that federal securities law preempts state law which may allow a cause of action for mere holders of the security); Blue Chip Stamps v. Manor Drug Stores, 421 U.S. 723, 736 (1975) (holding that the 10b-5 remedy is limited to buyers).

8. The extent of feedback ultimately depends on the number of shares represented by the plaintiff class. For example, if the holdings of the plaintiff class are equal to $50 \%$ of the outstanding shares, the decrease in the price of the subject stock will be twice what it would have been in the absence of a class action. The appendix sets forth the formula for calculating the feedback effect in both bad news and good news cases together with charts showing the results for various class sizes. See Richard A. Booth, The End of the Securities Fraud Class Action as We Know It, 4 Berkeley Bus. L. J. 1, 3-5 (2007) (describing the effects of the feedback mechanism). One of the supposed problems that led to the enactment of the Private Securities Litigation Reform Act of 1995 (PSLRA) was the fact that stock price seems to fall by more than it should when a company makes a corrective disclosure. Most observers attributed this to market overreaction to bad news. Fear trumps greed. Accordingly, PSLRA provides that rather than calculating damages by reference to market price immediately following corrective disclosure, damages shall be calculated by reference to the average closing price for 90 days following corrective disclosure. For a summary of thinking about crash damages as well as the problems with the PSLRA approach, see Booth, supra note 5, at 1045-46. The PSLRA approach seems to have been based on the assumption that market price usually springs back after the initial shock of corrective disclosure. But if the additional decline comes from feedback as described here, there is no reason to expect the market to rebound unless new information comes out that suggests that the claim is likely to be dismissed or that the claim is otherwise smaller than originally thought. That may be a good enough reason to provide for a cooling off period. Nevertheless, if the excess loss comes from feedback there is no reason to think that it would not be permanent, all other things being equal). Incidentally, if the overreaction theory is correct, one would expect traders to flock to fraud-affected stocks precisely because they are systematically underpriced. 
aggregate investment returns. The cure is worse than the disease. Securities fraud class actions serve only to reduce aggregate returns for diversified investors who thus should be positively opposed to them as a legal institution. ${ }^{9}$

In contrast, securities fraud class actions may make sense from the viewpoint of an undiversified investor. An undiversified investor may suffer real harm from securities fraud. For example, an investor who forgoes the benefits of diversification and picks a single stock can lose everything. To be sure, such an investor may gain if she happens to sell an overpriced stock. Moreover, such an investor may also lose as a mere holder if the subject stock becomes the target of a securities fraud class action because of events that occur after she buys. Nevertheless, for an undiversified investor, the benefits of securities fraud class actions may outweigh the costs. Just as one may gain peace of mind from buying insurance - even though one pays but never collects-an undiversified investor may find it a good deal to be (somewhat) protected against securities fraud by securities fraud class actions. ${ }^{10}$

9. It is ironic that the Supreme Court begins its recent Tellabs opinion with Justice Ginsburg's statement that the Court "has long recognized that meritorious private actions to enforce federal antifraud securities laws are an essential supplement to criminal prosecution and civil enforcement actions ...." Tellabs, Inc. v. Makor Issues \& Rights, Ltd., 551 U.S. 308,313 (2007). While the Court follows this statement with the qualification that it also recognizes that the system can be abused to impose unjustified costs on innocent companies and individuals, the tea leaves seem to indicate that the justices are not inclined to scrap the system. Interestingly, it appears that mutual funds and other institutional investors often forgo the opportunity to file claims in successful securities fraud class actions. See James D. Cox \& Randall S. Thomas, Leaving Money on the Table: Do Institutional Investors Fail to File Claims in Securities Class Actions?, 80 WASH. U. L.Q. 855, 879 (2002) (suggesting that institutions are often not filing claims in securities class action lawsuits). Although one might be tempted to argue that this constitutes some kind of evidence that institutional investors have recognized that securities fraud class actions are counterproductive, the fact is that failure to file a claim when others file is irrational (irrespective of whether one favors securities fraud class actions) and amounts to a subsidy running from funds to claimants. On the other hand, it may be that mutual fund investments tend to be concentrated in particular stocks and that failure to file a claim is more common in cases in which most other investors are also mutual funds, suggesting a form of consciously parallel behavior. See A.C. Pritchard, Who Cares?, 80 WASH. U. L.Q. 883, 883-88 (2002) (replying to Cox and Thomas). In any event, there has been a flurry of lawsuits recently against mutual funds that failed to file claims in securities fraud class actions. See Jonathan D. Glater, Suits Contend Mutual Funds Fail to Collect in Settlements, N.Y. TimES, Jan. 19, 2005, at C1. (reporting on these lawsuits against institutional investors).

10. An investor is somewhat protected because securities fraud class actions are usually settled and the amount recovered is seldom if ever equal to the full amount of the loss suffered by buyers. Moreover, the settlement is further reduced by litigation expensesprimarily attorney fees-which average about $20 \%$ of the award. And that does not include the cost to the defendant company, which further reduces the value of the fraud-affected stock. Thus, it is not completely clear that even an undiversified investor would favor the existing system if she understood that it causes stock price to fall more than it otherwise 
Thus, there is a fundamental conflict between the interests of diversified investors and the interests of undiversified investors. ${ }^{11}$ Diversified investors should be opposed to securities fraud class actions while undiversified investors may well favor such actions. Accordingly, the courts should decline to certify a securities fraud action as a class action because the conflicting interests of diversified and undiversified investors make it impossible for a class action to be prosecuted consistent with the interests of both groups of investors. Rule 23(a) of the Federal Rules of Civil Procedure requires that the court determine that the representative plaintiff(s) will fairly and adequately protect the interests of the class. ${ }^{12}$ That is impossible where the interests of class members are diametrically opposed-where one group would favor prosecution of the action and the other group would favor dismissal of the action. It does no good here for the courts to form subclasses or to rely on the right of investors to opt out of the class action. If the subclass of undiversified investors wins, the subclass of diversified investors loses. Yet if the action proceeds as a class action, diversified investors cannot afford to opt out because the company pays. By forgoing compensation, diversified investors effectively pay those who remain in the action just as if they declined to accept their share of a dividend paid by the company.

In addition to feedback loss, holders suffer a further loss because of the expenses suffered by the corporation in defending itself against the class action and any other enforcement proceedings (not to mention possible fines and the intangible costs of management distraction). ${ }^{13}$ Moreover, the corporation may suffer reputational harm that increases its cost of capital and further drives down stock price. ${ }^{14}$ Although buyers may

would. From an ex ante perspective such an investor is more likely to be a holder than to be a buyer and is thus more likely to lose because of feedback than to gain from being a member of the plaintiff class. Finally, if the plaintiff class is so large that success of the action threatens to bankrupt the defendant company and drive the stock price to zero, all investors may be better off if the action is dismissed and the company survives. For example, in the collapse of Enron, the market capitalization fell from $\$ 70$ billion to zero even though Enron was probably worth about $\$ 30$ billion as a going business. Michael C. Jensen \& Kevin J. Murphy, Remuneration: Where We've Been, How We Got to Here, What Are the Problems, and How to Fix Them 46 (European Corporate Governance Inst., Working Paper No. 44, 2004). In some cases the effect on the defendant business can be devastating. Indeed, about $30 \%$ of target companies end up bankrupt. 2005 REVIEW AND ANALYSIS, supra note 1, at 14 .

11. See Alexander, supra note 5, at 1506 (explaining the phenomenon in which the costs of the settlement are ultimately borne by the shareholders, particularly institutional investors who often only have interest in an action for its deterrence value).

12. FED. R. CIV. P. 23(a).

13. See Pfeiffer v. Toll, 989 A.2d 683 (Del. Ch. 2010).

14. Barbara Black, Reputational Damages in Securities Litigation, 35 J. CORP. L. 169, 174-75 (2009). But see Allen Ferrell \& Atanu Saha, The Loss Causation Requirement for Rule 10b-5 Causes-of-Action: The Implication of Dura Pharmaceuticals v. Broudo 19-24 
recover for these losses because they are built into the total decline in stock price, they are losses suffered by all of the stockholders and not merely those who bought during the fraud period. In such cases, diversified investors would not want the company to decrease its value still further by compensating buyers. Rather, diversified investors would prefer to have the company recover from the individual wrongdoers to restore company value. Finally, if insiders extract gains during the fraud period, either by means of insider trading or other forms of misappropriation, the company may have an additional claim for restitution that may be asserted in a derivative action. ${ }^{15}$

As a matter of prevailing practice, derivative claims are almost always addressed after class claims are resolved, even though recovery by the corporation would have the effect of reducing the aggregate damages suffered by the class. This is doubly troubling because class claims typically deplete the funds available from insurance. Thus, derivative claims are typically settled by the corporation adopting governance reforms of dubious value but without any monetary recovery by the corporation. In short, the class claims of buyers - who need no remedy because they can diversify - are favored over the very real claims of the corporation, whose recovery would redound to the benefit of all stockholders-buyers included.

This article proceeds as follows:

First, I discuss the characteristics of the investor population-at least two-thirds of which is very well diversified by virtue of investment through various institutional vehicles. I then discuss the reasons why diversified investors trade the stocks in their portfolios, and the attendant odds of investing in a stock that is the target of a securities fraud class action. Finally, I show why, with the exception of cases in which insiders have caused reputational harm to the issuer or have misappropriated stockholder wealth, diversified investors have nothing to gain from securities fraud class actions. Otherwise, securities fraud is a zero-sum game.

Second, I consider in more detail the elements of damages that may compose securities fraud class action awards and the character of each as either a direct claim or a derivative claim. I argue that there are four possible elements of damages: (1) the decrease in price from the disclosure of bad news (fundamental loss), (2) the decrease in price from the prospect of payout by the defendant company (feedback loss), (3) the decrease in

(Harvard John M. Olin Center for Law, Economics, and Business, Discussion Paper No. 08/2007, 2007) (discussing the financial implications of corrective disclosure); Baruch Lev \& Meiring de Villiers, Stock Price Crashes and 10b-5 Damages: A Legal, Economic, and Policy Analysis, 47 STAN. L. REV. 7, 10-11 (1994) (arguing that there should be no recovery for consequential damages in connection with securities fraud claims)

15. Pfeiffer, 989 A.2d at $691-95$. 
price from the direct expenses suffered by the defendant company (including attorney fees and expenses, and fines imposed by regulators) (litigation loss), and (4) the decrease in price from the perception that the subject company is riskier than previously thought and the increased cost of capital that goes with it (cost of capital loss).

This last element of damages may or may not be actionable. Cost of capital loss may come from the fact that the market has discovered new information about the company that indicates that the company is riskier than previously thought. Or it may come from a loss in trust resulting from management malfeasance. The decrease in price from management malfeasance - which is likely to be present in any meritorious case because of the scienter requirement under Rule 10b-5-is clearly derivative in nature. As such, it is a claim that belongs to all of the stockholders, not simply those who bought during the fraud period.

Third, I discuss the requirements of Rule 23 and show why securities fraud actions that seek damages on behalf of individual investors cannot meet these requirements. First, given the conflicting interests of diversified and undiversified investors, no one individual can be an adequate representative for both groups. Many if not most diversified investors lose more from a class action than they gain and would thus prefer that the action be dismissed. Second, a derivative action is superior to a class action for purposes of resolving the claims that are common to diversified and undiversified investors. Indeed, if a claim is derivative, it should be governed by Rule 23.1, and the question of class certification should not arise in the first place. Third, there are individual questions of reliance that must be addressed by undiversified investors. Although reliance may be presumed under the fraud on the market doctrine, this presumption extends only to diversified investors who are passive price-takers. By definition, an undiversified investor is a stock-picker who presumably has specific reasons for picking the stocks that he does. Thus, the very fact that such an investor is undiversified rebuts the presumption of reliance on market prices. Finally, it is up the court to manage the litigation. At the very least, it is up to the court to decide the order in which claims will be resolved. It is clear that claims that affect all of the stockholders should take precedence over claims affecting only undiversified investors.

Fourth, I address a variety of policy considerations that bolster the case against securities fraud class actions and the case for derivative actions. Specifically, I address the deterrence and compensation functions of securities fraud litigation and show that derivative actions provide a more proportional remedy on both counts. Moreover, I show that the law should presume that a reasonable investor is a diversified investor and that in any situation in which the interests of diversified investors diverge from those of undiversified investors (as they do in securities fraud litigation), 
the interests of diversified investors should trump those of undiversified investors.

\section{The MATHEMATICS OF SECURITIES FRAUd Class ACTIONS}

To understand investor preferences regarding securities fraud litigation, it is important to have some sense of the odds that an investor will be a buyer, a seller, or a holder of a target stock. That requires some sense of investor demographics.

\section{A. The Investor Population}

About two-thirds of all stock is held by very well diversified institutions such as mutual funds and retirement plans. ${ }^{16}$ This is not

16. According to Federal Reserve Board data, as of year-end 2006 there was an outstanding \$20.603 trillion in (publicly traded) equity of United States companies of which $\$ 5.483$ trillion was held by households and nonprofit institutions. L.213 Corporate Equities, in Flow of Funds Accounts of the United States, Flows and Outstandings Fourth QUARTER 2006 90. (Note that these figures do not include investment company shares.) Historically, nonprofits have accounted for about $9 \%$ of the equity holdings of the household sector. See L.100.a Nonprofit Organizations, supra at 109 (showing annual data for 1988 through 2000). This sector apparently also includes stock held by other corporations, but assuming that individual holdings equal $91 \%$ of the household sector (about $\$ 4.990$ trillion), institutions and not individuals own about $76 \%$ (roughly $\$ 15.135$ trillion) of all equities outstanding. Because institutions are fiduciaries, they are generally required to diversify under general principles of trust law or more specific statutes such as the Investment Company Act of 1940 and the Employee Retirement and Income Security Act (ERISA). See, e.g., Investment Company Act of 1940 § 5(b), 15 U.S.C. § 80a-5 (2011) (stating investment company may not be classified as diversified if it has more than $5 \%$ of its assets invested in any one issuer). Thus, it seems fair to presume that institutions are diversified. Federal Reserve Board data also indicated that $9.5 \%$ of families held fifteen or more stocks. Brian K. Bucks, Arthur B. Kennickell \& Kevin B. Moore, Recent Changes in U.S. Family Finances: Evidence from the 2001 and 2004 Survey of Consumer Finances, 92 Fed. Res. Bull., A1, A15 (Feb. 2006). That is a shockingly low number. See also William N. Goetzmann \& Alok Kumar, Equity Portfolio Diversification 23-24 (Nat'l Bureau Econ. Research, Working Paper No. 8686, 2001) (showing that individual investors are largely under-diversified). Nevertheless, if such investors are counted as diversified, total holdings of diversified investors are about $\$ 15.609$ trillion. Moreover, individuals ultimately hold the interests in the institutions that hold diversified portfolios. Studies indicate that an investor can achieve adequate diversification with as few as twenty different stocks. See Franco Modigliani \& Gerald A. Pogue, An Introduction to Risk and Return, 30 Fin. AnAL. J. 68, 74-75 (1974) (finding that a portfolio of twenty stocks can essentially eliminate company specific risk and will perform almost identically to the broader market); see also James M. Park \& Jeremy C. Staum, Diversification: How Much is Enough? (Nat'l Bureau Econ. Research, Working Paper No. 85428, 1998) (suggesting that while twenty is preferable, adequate diversification may be achieved with as few as five funds). It is not necessary for present purposes to know how much diversification is enough. It is sufficient to note that it is essentially costless for an investor to diversify and that the risk of securities fraud, like other types of company-specific risk, can be eliminated through diversification. Most 
surprising. One would expect most individual investors to invest through institutions, because that is the cheapest and easiest way to achieve diversification. Indeed, it is irrational for most investors not to be diversified. An undiversified investor assumes unnecessary risk for the same expected return that diversified investors enjoy. Moreover, since diversified investors assume less risk, they are willing to pay more for stocks. Accordingly, diversified investors drive up market prices. As a result, undiversified investors overpay because they pay market prices that are effectively set by diversified investors who perceive less risk. In any event, it is quite clear that most stock is held by diversified investors.

Diversification has implications for trading. There is little reason for a diversified investor to engage in much stock-picking. The point of diversification is to avoid the risk that goes with investing in individual stocks. Moreover, the cost of trading-including research and commissions - eats into investment returns. Further, it is impossible to beat the market without inside information. ${ }^{17}$ So, there is little reason to believe that diversified investors do much discretionary trading.

On the other hand, an investor can engage in some stock picking with very little risk as long as he stays diversified. It is common for individual investors to sell winners and losers in tandem in order to minimize taxes. To the extent that trading is so motivated, tax law dictates that if one sells a stock to recognize the loss, the funds cannot be reinvested in the same stock. Otherwise the transaction is ignored for tax purposes. This suggests that when diversified investors do trade, they often sell all of the stocks they choose to sell and replace them with new stocks. Since capital gains and the attendant tax benefits pass through to mutual fund investors, it seems fair to assume that mutual funds trade for these reasons as well.

Although stock picking and tax planning undoubtedly motivate some trading by diversified investors, another important reason for a diversified investor to trade is to maintain portfolio balance. Over time, some stocks will increase in value while others will decrease in value. To remain well diversified, an investor must periodically rebalance her portfolio by selling stocks that are overrepresented in the portfolio and by buying stocks that are underrepresented in the portfolio. ${ }^{18}$

individual investors diversify by investing in mutual funds and similar pooled investment vehicles. Thus, even a very small investor may invest in a fully diversified portfolio of 200 to 300 different stocks. While funds do charge a variety of fees in addition to the direct expenses of holding and trading portfolio securities, there are comparable fees and expenses involved in maintaining an individual account.

17. See Burton Malkiel, A Random Walk Down Wall Street 209-10 (6th ed. 1996) (suggesting that outside of insider trading there does not appear to be significant unexploited investment opportunities).

18. Note that trading for rebalancing may work in the opposite way as trading for tax reasons. 
To get a sense of how much trading is attributable to these strategies, we can look to readily available data on the trading habits of mutual funds. Over the years 1974 to 2009, average share turnover in all mutual funds has been about $58 \%$ per year. ${ }^{19}$ As one might expect, there is less share turnover in index funds. For example, Vanguard reports that average annual turnover in its index funds is about $14 \%$ for general domestic stock funds and about $32 \%$ for more aggressive domestic stock funds. Finally, annual turnover in the S\&P 500 index itself is about $5 \% .^{20}$

With this data, we can begin to estimate how often such an investor would be a buyer, a seller, or a holder of a fraud-affected stock. But, in

19. Investment Company Institute, 2010 Investment Company FaCt Book 28 (50th ed. 2010).

20. Richard A. Booth, The Buzzard Was Their Friend-Hedge Funds and the Problem of Overvalued Equity, 10 U. PENN. J. Bus. \& EMP. L. 879, 897 (2008). In contrast, market wide turnover among New York Stock Exchange listed stocks is about $130 \%$. Fact Book Online, NYSE Group Turnover, NYXDATA.COM, http://www.nyxdata.com/nysedata/asp/ factbook/main.asp (follow "Market Activity" hyperlink, then follow "NYSE Group Turnover" hyperlink). Recent studies estimate that in the United States, in the years since 2000 , only about twenty-four percent of all trading is motivated by stock picking. That figure appears to be on the decline. See, e.g., Utpal Bhattacharya \& Neal E. Galpin, The Global Rise of the Value-Weighted Portfolio (American Finance Association, Chicago Meetings Paper, 2007) (finding that about three-quarters of trading is motivated other than by stock picking). See also Martijn Cremers \& Jianping Mei, Turning Over Turnover (Yale ICF Working Paper No. 03-26, 2004); Meir Statman, et al., Investor Overconfidence and Trading Volume, (American Finance Association, San Diego Meetings Paper, 2003). But see Martijn Cremers \& Antti Petajisto, How Active is Your Fund Manager? A New Measure that Predicts Performance, (American Finance Association, Chicago Meetings Paper, 2007) (finding that more active managers of non-index funds outperform less active managers). For a treatment of trading frequency from a legal point of view. See Paul G. Mahoney, Is There a Cure for "Excessive" Trading?, 81 VA. L. REV. 713 (1995) (examining the role of securities regulation and regulation of financial intermediaries such as banks and mutual funds on trading frequency). See also Lynn A. Stout, Are Stock Markets Costly Casinos? Disagreement, Market Failure, and Securities Regulation, 81 VA. L. REV. 611 (1995) (discussing the need to revisit the laissez-faire structure of securities law, which encourages trading, if the heterogeneous expectations model, which questions the societal benefit of stock trading, accurately describes consumer stock purchasing decisions); Lynn A. Stout, Reply: Agreeing to Disagree over Excessive Trading, 81 VA. L. REv. 751, 755 (1995) (arguing "a purely laissez-faire approach to stock markets can invite welfare losses that might be avoided under a regulatory scheme designed to reduce the dispersion of investors' expectations, decrease the costs of their mistakes, or hasten their learning"). Bhattacharya and Galpin also find that in the United States in the 1960 s about $60 \%$ of trading was motivated by stock picking. They predict that the level of stock picking will continue to decline and stabilize at about $11 \%$. It is not surprising that securities fraud class actions became established at a time when most investors focused on company-specific factors. Bhattacharya \& Galpin, supra, at 19-20. It is possible that the mix of investors varies from one corporation to the next. For example, it is possible that a particular corporation may attract the disproportionate attention of stock pickers. But for most companies, most trading appears to be motivated by other factors. 
order to complete the picture, one also needs data about the population of public companies and the frequency of securities fraud class actions.

\section{B. Trading Style and the Effect of Litigation}

There are about 6100 publicly traded companies listed on US stock exchanges. ${ }^{21}$ On average there are 195 securities fraud class actions filed each year. ${ }^{22}$ Thus, on average, about one in thirty-one companies will be the target of a class action in any given year.

Consider an investor with a $\$ 1,000,000$ portfolio consisting of 500 stocks that are equally weighted by dollar value. In other words, the investor holds $\$ 2000$ worth of each of the 500 stocks. Assume that turnover is $14 \%$ per year, the average of Vanguard index funds, and that when an investor sells a stock, she sells all of that stock that she owns and uses the proceeds to buy another stock that she does not currently hold. Thus, the investor sells $\$ 140,000$ in 70 different stocks and buys $\$ 140,000$ in seventy other different stocks during the course of a year. On average, the investor can expect that a class action will be filed in connection with about two of the stocks she sells, two of the stocks she buys, and fourteen of the stocks she holds. ${ }^{23}$ Assume further that each of the fraud-affected stocks would have fallen in price by $10 \%$ based solely on the disclosure of bad news (without any feedback effect). Finally, assume that the plaintiff class comprises $50 \%$ of the company's stockholders in each case.

In a world without securities fraud class actions, the hypothetical investor would lose $10 \%$ of the value of each of the two stocks she buys and the fourteen stocks she holds. She would avoid losses on the two stocks she sold. ${ }^{24}$ Her total loss would thus be $\$ 3200$.

In a world with securities fraud class actions, each fraud-affected stock would decline in value by $20 \%$ or $\$ 400$. That is, it would decline $\$ 200$ from the fundamental decline in price and $\$ 200$ more from the feedback effect that results from the payout to the plaintiff class. ${ }^{25}$ Thus, the investor

21. Author analysis of Center for Research on Securities Prices ("CRSP") data through 2008 (on file with author). The number of public companies has decreased rather dramatically from a high of 9027 in 1997 because of new SEC and NASDAQ rules that require all companies traded on an electronic quotation system to be registered for purposes of continuous reporting under the 1934 Act.

22. 2010 REVIEW AND ANALYSIS, supra note 1, at 1. This includes a small number of foreign companies. See data in Appendix infra.

23. This assumes that the average fraud period is one year. And indeed the average fraud period is about 300 days. Study on file with author.

24. It could be said that the investor actually enjoys a gain by selling the two overpriced stocks. The point here is only to compare the ending value of the portfolio with and without a class action remedy.

25. If the plaintiff class comprises $50 \%$ of the outstanding shares, the feedback effect in a bad news case will cause the stock price to decline by exactly twice the amount that it 
would recover her losses on the two stocks she bought, less fees and expenses. Assuming fees and expenses equal to $20 \%$ of recovery- $\$ 80$ for each stock-her net loss would be $\$ 160 .^{26}$ Again, she would avoid losses on the two stocks that she sold, but she would lose $\$ 400$ on each of the fourteen stocks that she held. The investor's total loss would thus be $\$ 5600$.

Finally, if the investor opted out of the two class actions in which she was a member of the plaintiff class, she would lose $\$ 400$ on each of those two stocks, for a total loss of $\$ 6400$, including both stocks bought and stocks held. The following chart sets forth these results:

\begin{tabular}{|l|r|r|r|}
\hline & NO CLASS ACTION & CLASS ACTION & OPT OUT \\
\hline BUY $(2)$ & $(400)$ & $(160)$ & $(800)$ \\
\hline HOLD $(14)$ & $(2800)$ & $(5600)$ & $(5600)$ \\
\hline TOTAL & $(3200)$ & $(5760)$ & $(6400)$ \\
\hline
\end{tabular}

Clearly, this investor would be better off in a world without securities fraud class actions. But, if any of the class actions in which she is a buyer proceeds, she would decline to opt out because by doing so she would be even worse off. Moreover, and for similar reasons, this investor would favor a class action remedy if it is likely that class actions will be prosecuted in the cases in which she is a mere holder. If class actions are prosecuted in these cases, she loses as a holder because buyers get paid. So she would want the class action to proceed when she is a buyer in order to get her fair share of the total pot. In short, securities fraud class actions give rise to a classic market failure in which investors behave contrary to their true interests.

would have declined in the absence of a class action. The appendix to this paper includes the relevant formulas and calculations. This decline does not include losses from litigation expenses or increased cost of capital. These elements of damages are discussed further below.

26. Again, plaintiff attorney fees and other litigation expenses are paid out of the settlement. These fees and expenses average about $20 \%$ of the gross settlement amount. See supra note 1 and accompanying text. The calculations here assume that the total recovery (gross before litigation expenses) is equal to $100 \%$ of the investor loss. That is never the case. But if the recovery is less than $100 \%$ the loss on stocks held should be reduced too. 
The assumption in the above analysis is that the investor trades at a turnover rate of $14 \%$. Needless to say, investors may trade more or less than at that rate. The following chart shows how investors fare when they trade at different turnover rates:

\begin{tabular}{|l|r|r|r|r|r|}
\hline TURNOVER & $0 \%$ & $10 \%$ & $25 \%$ & $50 \%$ & $100 \%$ \\
\hline BUY & $0 / 0$ & $2 /(160)$ & $4 /(320)$ & $8 /(640)$ & $16 /(1280)$ \\
\hline HOLD & $16 /(6400)$ & $14 /(5600)$ & $12 /(4800)$ & $8 /(3200)$ & $0 / 0$ \\
\hline TOTAL & $(6400)$ & $(5760)$ & $(5120)$ & $(3840)$ & $(1280)$ \\
\hline
\end{tabular}

As the chart shows, investors who trade relatively little are the big losers from securities fraud class actions. Ironically, the conventional wisdom is that the best investment strategy is to buy and hold since it is impossible to beat the market picking stocks and since trading is costly. Yet securities fraud class actions punish such investors in effect by transferring wealth to investors who engage in stock-picking and trade more often. In other words, securities fraud class actions are doubly inconsistent with the interests of reasonable investors. They protect against risks that can more cheaply be avoided through diversification, and they penalize investors who follow a buy and hold strategy. ${ }^{27}$

\section{Portfolio Balancing}

The foregoing analysis is somewhat unrealistic. In the real world, a diversified investor often buys more of a stock that is already in her portfolio or sells some but not all of the shares of a stock in her portfolio simply to rebalance the portfolio. ${ }^{28}$ For example, suppose that one of her

27. Although the chart is reasonably realistic at lower levels of turnover, it suggests somewhat unrealistically that an investor who trades at a turnover rate of $100 \%$ would suffer no holding losses. This might be close to true if the investor sold every stock every year and replaced those stocks with other stocks. But it is probably more typical for an investor to hold some stocks for longer periods and to trade some stocks even more often than once a year. In other words, the turnover rate is an average. But even if an investor trades every stock in his portfolio for a different stock every year, the average fraud period of about one year is itself an average. So the investor will likely be a holder of some stocks with relatively short fraud periods.

28. See, e.g., Carla Fried, 3 Men, 3 Strategies, But All Lead to Profit, N.Y. TIMES, Apr. 10,2005 , at B30 (using rebalancing to take emotion out of investing and give investments time to work out); Mark Hulbert, If You Know Options, You're Likely to Know Stocks, N.Y. TIMES, Aug. 13, 2006, at B7 (showing that rebalancing options in a portfolio can be a highly successful trading strategy); Paul J. Lim, Cash May Not Be King, but It's Wielding More Power, N.Y. Times, July 9, 2006, at B5 (discussing the impact of historical returns on cash on portfolio management strategies); Paul J. Lim, Hitting the Reset Button on Your 401(k), N.Y. TIMES, Jan. 8, 2006, at B5 (detailing the importance of rebalancing a 401(k) portfolio for the average investor); Paul J. Lim, When It Comes to Rebalancing, a Little Means a Lot, 
500 stocks - Acme Fireworks - has decreased in total value to $\$ 1500$ while another-Binford Tools - has increased to $\$ 2500$. She sells $\$ 500$ worth of Binford and buys $\$ 500$ worth of Acme to rebalance her portfolio. Shortly after these trades, Acme announces a restatement of earnings. Analysts revise their long-term projections for Acme downward by 10\%. Acme should decrease in price by $10 \%$ (other things equal). But the stock settles at a price $20 \%$ lower because of the feedback effect from an anticipated class action. Indeed, a class action is filed on behalf of investors who bought Acme during the fraud period. On paper, the investor has lost $\$ 400$ on her Acme investment. But she has standing to sue only with respect to the $\$ 500$ purchase and hence stands to recover at most $\$ 100$ less $\$ 20$ in fees and expenses or $\$ 80$ net. So her best-case loss on Acme stock will be $\$ 320$. In the absence of a class action, the decline would be $10 \%$. And the investor would have a lost a total of $\$ 200$ on her Acme investment.

Clearly, this investor would oppose class certification irrespective of any other fraud-affected stocks she might hold. In the previous example, where the diversified investor is assumed to trade all or nothing, she might want the class action to proceed so she can get her fair share on the assumption that she will effectively pay in all of the cases where she is a holder. But not so for a portfolio-balancing investor. She would want the court to deny certification of the action as a class action. If the class action proceeds, she must seek her share of the recovery. As with the all-ornothing trader, it would do no good for the portfolio-balancing investor to opt out of the class action. ${ }^{29}$

N.Y. TimES, Aug. 5, 2007, at B5 (presenting rebalancing as means to mitigate the impact of market volatility on securities portfolios); Joseph Nocera, No, You Can't Invest Like Yale. Sorry!, N.Y. TIMES, Aug. 13, 2005, at C1 (analyzing Yale's portfolio approach to investing its endowment); J. Alex Tarquinio, Oops, It May Be Time to Rebalance That Portfolio, N.Y. Times, May 6, 2007, at C4 (encouraging investors to rebalance their portfolios to take advantage of the benefits of asset class diversification). It is also quite common for investors to engage in dollar cost averaging. That is a roundabout way of saying that they invest over time as they accumulate savings. Such a strategy is similar to portfolio balancing. Indeed, unless a dollar cost averaging investor chooses new stocks for each new addition of cash to his portfolio, he effectively engages in portfolio balancing by default.

29. The assumption in the foregoing discussion has been that portfolio-balancing investors buy because the value of the subject shares in their portfolios has declined below some target percentage. That can happen in several different ways: (1) the shares may have fallen in value, (2) the remainder of the market may have risen in value, or (3) investors may have added cash to their portfolios. In addition, there is more than one way to balance a portfolio. For example, an index fund typically seeks to hold shares in proportion to market capitalization (or public float). Thus, an index fund will be a buyer when the price of the subject stock rises relative to the rest of the market. In other words, portfolio balancing may lead some investors to sell and other investors to buy. Because of the mix of investor strategies, it is quite possible for portfolio-balancing investors to account for a large proportion of the class. Moreover, since index funds (and indeed all funds) tend to buy stocks that increase in value, and since fraud-affected stocks are by definition overvalued, it 
In the end, it seems likely that portfolio-balancing investors dominate the investor population simply because two-thirds of all stock is held by well-diversified institutions. But it is not the point here to determine what style of investing predominates. It is enough to show that a significant number of investors in any plaintiff class will be opposed to class action certification because they will lose more than they will win if the class action succeeds. In other words, it is not necessary to show that all diversified investors would oppose certification. It suffices to show that the interests of investors differ enough that the courts should decline to certify securities fraud actions as class actions. ${ }^{30}$

\section{The Relevance of Insurance}

To be clear, the idea that some investors lose more than they gain from a class action ultimately depends on the fact that the stock price of the defendant company falls by more than it should as a result of the feedback effect that arises because the company pays. It might be argued that where the award is covered by insurance (as it usually is), there may be no feedback effect and no reason for anyone to object to class certification. Indeed, many cases are settled for whatever amount is available from the defendant company's insurance. There are several responses to the idea that insurance may eliminate feedback.

First, we should assess the social value of securities litigation (and any other legal right or obligation) on its own merits. The law is that the defendant company compensates buyers who suffer a loss. The fact that the bill may be paid by an insurance company is irrelevant. There would be no bill but for the imposition of liability. That is why evidence of insurance is generally inadmissible. ${ }^{31}$

Second, if insurance is depleted by securities litigation it will be unavailable for other purposes. For example, if the defendant company is sued for products liability or pollution, there will be no insurance coverage remaining. If the company must pay other claims out of its own pocket, it may fail altogether. In a sense, insurance is part of the capitalization of the company in that it protects the company from unforeseeable major

may be that funds are somewhat more likely to be buyers of fraud-affected stocks than they are to be sellers. On the other hand, many individual investors (traders) seem to focus on momentum. So they may also be unusually inclined to buy fraud-affected stocks. But since momentum investors tend to be active traders, they are also more likely to have sold a fraudaffected stock before corrective disclosure.

30. The appendix includes an extended discussion of portfolio balancing including examples of some extreme situations in which portfolio-balancing investors may favor class actions.

31. See FED. R. Evid. 411 (stating evidence of insurance is inadmissible to prove negligence or wrongdoing). 
expenses. $^{32}$ So it is not costless — nor a matter of sunk cost— to have the insurer pay.

Third, if the insurance company pays, the insured will pay higher rates for insurance in the future. That reduces expected return and thus stock price. So in the end it really makes no difference whether the insurance company pays. When the insurance company pays, it really only finances the award. In effect, the defendant company pays over time. Thus, there is good reason to think that feedback happens whether or not the award is paid by insurance.

Fourth, when an insurance company pays, rates go up for all potential defendant companies. Every successful securities fraud action raises the risk of future such actions. When insurance rates go up, investor returnand hence stock price-goes down. In other words, the feedback echoes throughout the market. Thus, diversified investors may lose even more as holders of stocks other than fraud-affected stocks. So diversified investors may well oppose certification even in cases in which they might appear to gain if the effect is measured simply with regard to the fraud-affected stock.

Needless to say, when a third party such as a tort victim makes a claim against a corporation, she wants to collect as much as possible. It does not matter if insurance coverage for other claims is thus reduced, or if premiums increase and the market value of the company declines, or if the company is rendered bankrupt in the process. But where the claimant is a stockholder as in the typical securities fraud class action, there is a conflict between the interests of stockholders who would collect and stockholders who would not. Indeed, even for stockholders who would collect there is a downside in that they may do more harm to the value of the stock they hold than they recover on the stock they bought. The situation is really no different from one in which a homeowner or an automobile owner may decline to make a claim for fear that his rates will increase in the future or that his insurance will be cancelled. In short, the fact that securities fraud class action settlements are often paid by insurance is irrelevant to the question of whether such actions are consistent with the interests of investors.

\section{THE ELEMENTS OF DAMAGES}

The foregoing discussion has focused on the conflicts between investors who benefit from securities fraud class actions and investors who lose from them. The fact that a significant number of potential class

32. See Radaszewski v. Telecom Corp., 981 F.2d 305, 310 (8th Cir. 1992) (stating that the issue of insurance is unquestionably related to capitalization). 
members would object is a sufficient reason to deny certification, but it is not the only reason to do so. Investors who would oppose certification would also presumably favor prosecution of a derivative action since in any meritorious case a significant part of the decrease in stock value will be the result of expenses incurred by the defendant company in connection with the litigation-including attorney fees and possibly fines as well as amounts paid out to the plaintiff class. Moreover, to plead a valid claim under Rule 10b-5, it must be shown that high-level officers of the defendant company acted with scienter - that they deceived the market with some sort of intent. ${ }^{33}$ Thus, it seems likely that in any action that survives a motion to dismiss, the company will suffer reputational harm that will have the effect of increasing its cost of capital and further decreasing its stock price. Finally, the issuer company may also have a claim for restitution if there has been insider trading or misappropriation of some other sort.

To be clear, it is not the argument here that buyer-holders should have a claim under federal law as holders. The law is well settled that only buyers have standing to sue under Rule $10 \mathrm{~b}-5 .{ }^{34}$ Holders have no claim under Rule 10b-5 simply because stock price fell. Nevertheless, holders (including buyers) may have a derivative claim based on the theory that management malfeasance caused the stock price to fall further than it would have fallen if management had simply told the truth when it should have done so. Indeed, federal securities law expressly preserves the right of stockholders to assert derivative claims under state law irrespective of whether the named plaintiff is a buyer or a holder and when such claims are ultimately based on a theory of non-disclosure. ${ }^{35}$

At first blush, it might seem that an undiversified investor should have no objection to a derivative action. Indeed, it is quite common in the real world for a class action and a derivative action to proceed side-by-side. ${ }^{36}$

33. The Supreme Court defined scienter in Ernst \& Ernst v. Hochfelder, 425 U.S. 185, 194 (1976), as intent to manipulate, deceive, or defraud.

34. See Blue Chip Stamps v. Manor Drug Stores, 421 U.S. 723, 736 (1975) (holding the private right of action under $10 \mathrm{~b}-5$ is limited to those who actually purchase or sell securities).

35. See Merrill Lynch, Pierce, Fenner \& Smith, Inc. v. Dabit, 547 U.S. 71,87 (2006) (stating that the Securities Litigation Uniform Standards Act ("SLUSA") preempted class actions by non-traders but that SLUSA preserved derivative actions brought by shareholders on behalf of a corporation). The implications of SLUSA are discussed in more detail below.

36. It appears that the number of side-by-side derivative actions has increased significantly in recent years. About $45 \%$ of all cases settled in 2009 were accompanied by derivative actions. Although this number is down somewhat from $55 \%$ in 2007, it is up significantly from $35 \%$ in 2005 . Ellen M. Ryan \& LAura E. Simmons, Cornerstone Research, Securities Class Action Settlements, 2009 Review and Analysis 11 (2009) [hereinafter 2009 REVIEW AND ANALYSIS]; 2005 REVIEW AND ANALYSIS, supra note 1, at 11. Moreover, although derivative actions are often settled in exchange for governance reforms and without any explicit monetary damages, the settlement amount in class actions 
But there are subtle conflicts between the two actions. In a derivative action, the award (if any) goes to the company. The fact that the company recovers means that its stock price should rise somewhat, thus decreasing any award in the class action. Accordingly, it seems quite clear that the derivative action must be resolved first before the class claim can even be measured. But in practice a derivative action is usually treated as an afterthought - a claim to be dealt with after the class action claim is resolved. $^{37}$

The interrelationship of derivative claims and class claims is easier to see in the context of an example. Suppose that Duff Brewing Company has one million shares outstanding and trades for \$20 per share for a market capitalization of $\$ 20$ million. The analysts expect Duff to report earnings of $\$ 2.00$ per share for the coming year. Thus, Duff trades at ten times expected earnings. In other words, the market values Duff stock such that its expected return on equity - its cost of equity - is ten percent.

Duff management has failed to disclose that several restaurant chains have decided not to serve Duff beer because it is inexplicably loaded with cholesterol. When the news finally comes out, the analysts revise their earnings predictions to $\$ 1.50$ per share.

One might expect Duff stock thus to fall to $\$ 15$ per share other things equal. But Duff shares fall to $\$ 10$ per share. Duff now trades at 6.66 times earnings. In other words, the market values Duff stock such that its cost of equity is $15 \%$. What accounts for the additional decrease in price and the increase in the cost of equity? There are two (or three) possible answers.

First, the additional decline may have come from the prospect of securities litigation. Although one might have thought that Duff would now be worth a total of $\$ 15$ million, maybe the market thinks that it will be required to pay out $\$ 5$ million in damages to those who bought during the fraud period. (I refer to this portion of the loss as feedback damages.) In addition, Duff is likely to suffer significant expenses in defending itself, including substantial attorney fees as well as the cost of management distraction. Duff may also pay out substantial sums in fines as well as

accompanied by derivative actions tends to be higher than in stand-alone class actions. See 2009 REVIEW AND ANALYSIS, supra note 36, at 11 (showing that lawsuits with derivative action settle for a median of $\$ 11.8$ million while lawsuits without derivative action settle for \$5.2 million).

37. See, e.g., In re Cendant Corp. Litig., 264 F.3d 201, 243-46 (3d Cir. 2001) (holding derivative plaintiff could not intervene in or stop investor class action suit against corporation and individual directors). See also In re Chambers Dev. Sec. Litig., 912 F. Supp. 822, 841 (W.D. Pa. 1995) (describing a derivative action as a mere appendage and discussing proposed settlement in which entire amount to be recovered by the corporation would go to derivative plaintiff counsel, or if not approved, into class action pot). But see In re Zoran Corp. Derivative Litig., 511 F. Supp. 2d 986 (N.D. Cal. 2007) (rejecting settlement because of minimal payment proposed). 
increased insurance premiums going forward. (I refer to this portion of the loss as litigation damages.)

Second, another possibility is that the market now sees Duff as riskier than it did before the bad news came out. So instead of requiring a $10 \%$ return on equity, the market now requires a $15 \%$ return on equity. (I refer to this portion of the loss as cost of capital damages.)

This second possibility itself may come from two distinct sources. It may be that the market learned something new about the beer business from these events and now sees brewing companies in general as riskier than previously thought. Or it may be that the market has lost trust in Duff in particular because of the cover-up of information about cancelled restaurant contracts. The market may suspect that there is more bad information that is being covered up or that when bad things happen Duff will not inform the market as promptly as it should. ${ }^{38}$

Needless to say, the additional decline in the value of Duff stock may be attributable to some combination of these factors. But the important point for present purposes is that these elements of damages that constitute the additional \$5 decline in excess of the expected decline from \$20 to $\$ 15$ - are claims that should be characterized as derivative because they affect all Duff stockholders in the same way. This is easiest to see if the claim is based on a loss of trust theory. If the company must now pay $15 \%$ for equity because the market distrusts management, it seems quite clear that the company as a whole has been damaged. On the other hand, the increased cost of equity may also be perfectly innocent. It may be that the market simply learned something new about the brewing business. It is not really important to resolve the question whether the increase in the cost of equity can be traced to an innocent or actionable source. That can be resolved at trial. The important point is that the claim is derivative. ${ }^{39}$

38. This is a classic market for lemons problem. See George A. Akerlof, The Market for "Lemons": Quality Uncertainty and the Market Mechanism, 84 Q.J. Econ. 488, 490-93 (1970) (discussing used car market as an example of how asymmetric information can reduce overall quality in a market by causing good quality producers to leave the market to avoid being tainted by actions of lower quality peers).

39. It should be relatively easy to determine whether the excess decline is innocent or actionable. If it is innocent then all comparable companies should have been similarly affected by the news. If the excess decline is peculiar to the defendant company, then it presumably comes from actionable reputational harm. (It is also possible that loss attributable to an increase in the cost of equity may come from both innocent and actionable sources. But again it should be easy enough to sort these out by reference to comparable companies). This determination is somewhat complicated by the possibility that some of the excess decline may be attributable to the prospect of payout - feedback damages. But in practice it should not matter much. Presumably, the class action will be dismissed in the absence of pleaded facts giving rise to a strong inference of scienter. 15 U.S.C. $\S 78 \mathrm{u}-4$ (2010). In most cases where the increase in the cost of equity is actionable, there will also be feedback damages. And in most cases where the increase in the cost of equity is 
A similar analysis applies if the excess loss comes from feedback and other costs or expenses associated with securities litigation. If the company declines in value by more than it should - by more than $\$ 5$ - this excess loss is one that affects all of the stockholders in the same way. So holders (together with buyers) clearly have a valid derivative claim for this element of damages. The corporation has suffered an injury because of the malfeasance of high-level officers to the extent that it has been required to pay the claims of fraud victims. If there had been no fraud, the corporation would be that much better off.

There can be little doubt that a corporation is harmed when the actions of its directors or officers result in an increase in the cost of capital. Accordingly, there can be little doubt that under the proper circumstances directors and officers can be held liable for such an injury to the corporation. ${ }^{40}$ Although one might object that the derivative claim arises in part as a result of the class claim - because of feedback-it is nonetheless clear that such an injury to the value of the corporation gives rise to a claim in the right of the corporation. ${ }^{41}$ Buyers can recover under Rule 10b-5 only

innocent, there will be no feedback damages. In other words, it is likely that either both elements of damages will be present or neither element will be present. To be sure, this assumes that defendant companies do not pay except in meritorious cases. That is not clearly true. See Janet Cooper Alexander, Do the Merits Matter? A Study of Settlements in Securities Class Actions, 43 STAN. L. REv. 497, 499-501 (1991) (finding little relation between the merits and the settlement values of securities class actions). But it is not clearly relevant either. Any time the company pays there will be a colorable derivative claim that arises from the loss in value attributable to the payout. Moreover, if there is no class action, there is no feedback. Thus, in a world without class actions, it will be that much easier to measure any loss from an increase in the cost of capital.

40.Although I have found no case that explicitly discusses an increase in the cost of capital as a loss, Delaware law recognizes that the board of directors may be held liable in a properly pleaded derivative action for any loss from a breach of the duty of candor-a failure of disclosure - even in the absence of a request for stockholder action. See Malone v. Brincat, 722 A.2d 5, 10 (Del. 1998) (stating directors have fiduciary duties to shareholders whenever they communicate with them either publicly or directly). See also In re Cendant Corp. Litig., 264 F.3d at 241-42 (holding a corporation might be able to recover from its officers and agents as a result of losses suffered from an improvident settlement of a securities fraud class action). Moreover, there are a number of cases that recognize that the directors and officers may be held liable for paying too much or accepting too little even though there are relatively few cases that ultimately hold directors or officers liable for such losses. See, e.g., Joy v. North, 692 F.2d 880, 886 (2d Cir. 1982) (finding potential liability for bank directors who continued to authorize loans to indebted builder in "no-win" situation); Smith v. Van Gorkom, 488 A.2d 858, 864 (Del. 1985) (holding directors liable for failing to properly inform themselves about the origins and financial merits of a merger orchestrated by the CEO).

41. See Stone v. Ritter, 911 A.2d 362, 370-73 (Del. 2006) (discussing a derivative action based on fines paid because of money laundering violations); Graham v. AllisChalmers Mfg. Co., 188 A.2d 125, 130-33 (Del. 1963) (discussing a derivative action based on allegations of antitrust violations); In re Caremark Int'l, Inc. Derivative Litig., 698 A.2d 959, 960-66 (Del. Ch. 1996) (discussing a derivative action based on fines and civil claims 
if they can show that directors or officers acted with scienter in failing to disclose material information to the market. ${ }^{42}$ The same standard applies under state law. The business judgment rule protects directors and officers from liability only for actions taken in good faith. If it can be shown that their actions were the result of a breach of the duty of loyalty-which includes actions taken in bad faith - or were not in fact the product of a valid business judgment-which is the same thing - the business judgment rule does not apply. ${ }^{43}$ The same is true if the corporation has adopted an exculpatory provision, such as under Delaware General Corporate Law section 102(b)(7), which clearly does not extend to actions taken other than in good faith. ${ }^{44}$ In short, neither the business judgment rule nor an exculpatory provision applies if a director or officer acted with scienter. ${ }^{45}$

for violations of Medicare anti-referral rules). The law is also clear that the business judgment rule does not protect directors from liability to the corporation for illegal actions even if they are somehow for the benefit of the corporation. See Miller v. AT\&T, 507 F.2d 759, 761, 763-65 (3d Cir. 1974) (discussing a corporation that neglected to insist on payment due to it from political party even though failure to collect amounted to an illegal campaign contribution); Metro Commc'ns Corp. BVI v. Advanced Mobilecomm Techs., Inc., 854 A.2d 121,131 (Del. Ch. 2004) (explaining that a fiduciary may not manage a corporation in an illegal fashion even if to do so would increase profits). Admittedly, all of these cases involved criminal actions albeit in combination with civil actions. But there is nothing in the concept of the duty to monitor that limits it to criminal activity. Moreover, securities fraud can be and often is prosecuted as a criminal matter as well as a civil matter. In Stone, Graham, and Caremark, the issue was whether the board of directors could be held liable to the stockholders for a failure to monitor the activities of subordinate officers that led to losses suffered by the corporation in connection with violations of law. Although none of these cases resulted in a finding that the board of directors was in fact liable, none of the cases was dismissed for failure to state a claim. In other words, each of the cases stated a valid cause of action against the board of directors. A fortiori the corporation would have a valid claim against subordinate officers who actually caused the loss even if directors cannot be held liable. One might object to the foregoing analysis because the elements of a fraud claim under federal law are quite different from the elements of a claim for breach of fiduciary duty under state law-typically Delaware law. Thus, for a court to rule that some elements of damages should be recovered in a derivative action would effect a substantive change in investor rights. There are two responses. One is: so what? If the claim is in fact in a derivative action, it should be litigated as such. The fact that no one has noticed the distinction up to now is of no moment. Another (perhaps less flippant) response is that there is not really any difference between federal and state law in this regard.

42. 17 C.F.R. $\S 240.10 b-5$ (2012).

43. Del. Code Ann. tit. 8, § 144(a) (2012).

44. Del. Code AnN. tit. $8, \S 102($ b)(7) (2012).

45. See Wood v. Baum, 953 A.2d 136, 141 (Del. 2008) (demonstrating that where directors are exculpated from liability, except for claims based on fraudulent, illegal, or bad faith conduct, plaintiff must plead particularized facts that demonstrate directors acted with scienter - that they had actual or constructive knowledge that their conduct was legally improper); Desimone v. Barrows, 924 A.2d 908, 945 (Del. Ch. 2007) (demonstrating that where directors are exculpated from liability, except for claims based on fraudulent, illegal, or bad faith conduct, plaintiff must plead particularized facts that demonstrate directors acted with scienter); see also In re Walt Disney Co. Deriv. Litig., 907 A.2d 693, 753-56 
Thus, whenever there is a valid buyer claim, there is by definition, a valid derivative claim. Assuming that scienter means the same thing in state court as it does in federal court, any such finding in a federal court ought to be good enough for a state court. So it seems likely that the same standard of behavior would apply to any claim based on an increase in the cost of capital as applies in the typical securities fraud class action. The point is that if there is a valid claim, it is derivative at least in part. ${ }^{46}$

\section{A. Derivative Actions in Practice}

The problem is that under federal law, investors who bought during the fraud period have a claim for the entire $\$ 10$ loss they suffered. ${ }^{47}$ As we have seen, $\$ 5$ of that loss is in fact a derivative claim that affects all of the shares in exactly the same way. The company lost value - over and above the decrease in price that came from the bad news itself-because of management malfeasance in handling the disclosure of the bad news. The claim for the additional loss should thus be asserted by or on behalf of the company against directors, officers, or other agents for the benefit of all of the stockholders. But the question is when should the derivative claim be asserted?

Given that the class claim is a federal claim and that the derivative claim is a state claim, one might assume that the federal claim should take precedence and should be resolved first. ${ }^{48}$ That is the standard practice

(Del. Ch. 2005) (demonstrating that intentional harm clearly constitutes bad faith).

46. This is not to suggest that a derivative claim based on an increase in cost of capital — or other harms - will arise only in cases giving rise to a class action under Rule 10b-5. Indeed, such claims may well arise in situations in which buyers have no federal claim.

47. At least this is the standard approach to damages as a matter of current practice. The Supreme Court has never ruled on what should be the measure of damages in a securities fraud class action. Indeed, the Court expressly reserved the question in Basic, Inc. v. Levinson, 485 U.S. 224, 242 (1988). On the other hand, this is the approach to damages on which Congress relied in PSLRA. It is arguable that it is implicit in statutory law. Moreover, one could argue that the Supreme Court effectively endorsed this approach in Dura Pharm., Inc. v. Broudo, 544 U.S. 336 (2005) in holding that proof of loss causation requires a price correction. Accord In re Initial Pub. Offering (IPO) Sec. Litig., 471 F.3d 24 (2d Cir. 2006). See also Emergent Capital Inv. Mgmt., LLC v. Stonepath Grp., Inc., 343 F.3d 189, 196-97 (2d Cir. 2003) (demonstrating that a plaintiff must allege price correction to plead loss causation).

48. But see Brandin v. Deason, 2007 WL 2088877 (Del. Ch.) (declining to defer to a derivative action later filed in federal court where the federal securities law claims were predicated on the same conduct giving rise to the state law derivative claims). It is possible that the derivative claim also arises under federal law. For example, one could argue that reputational harm suffered by the corporation is in connection with trading in its stock and thus within the contemplation of Rule 10b-5 even though the corporation itself did not buy or sell any stock. Indeed, federal securities law expressly contemplates recovery by the corporation (via derivative action if necessary) in cases of short-swing trading even though 
when a derivative claim is filed alongside a class claim. Indeed, the monetary recovery almost always goes to the class, while the derivative claim is typically settled by the corporation adopting governance reforms or other similar nonmonetary measures of dubious value. (Nevertheless, the plaintiff lawyers in a "successful" derivative action usually get paid well for their work).

As suggested above, there are good reasons why the derivative action should be resolved first. To be specific, it is impossible to know how much damage the buyers have suffered until it is determined how much of the price decrease is attributable to litigation expense or an increase in the cost of capital since if the corporation recovers in the derivative action its stock price will presumably rebound to reflect the recovery. ${ }^{49}$ But there are other more compelling reasons why the derivative claim should be resolved first.

To return to the Duff Beer example, recall that stock price falls from $\$ 20$ to $\$ 10$ on news that should have caused a decrease only to $\$ 15$. Thus, buyers suffer a loss of $\$ 10$ per share. Assume (1) that $\$ 2$ per share of the damages is attributable to litigation expense or an actionable increase in the cost of capital, (2) that $\$ 3$ per share in damages is attributable to feedback, and (3) that the plaintiff class consists of $30 \%$ of the shares $(300,000$ shares). ${ }^{50}$

\section{Scenario I}

If the class action is litigated first, the class recovers $\$ 3 \mathrm{M}$ and stock price settles at $\$ 10$. The corporation then recovers $\$ 5 \mathrm{M}$ in the derivative action and stock price climbs back to $\$ 15$. In the end, the class is overcompensated. Since stock price finally settles at $\$ 15$, the class should have recovered only $\$ 1.5$ million.

the corporation itself did not trade. See Securities Exchange Act of $1934 \S 16(b), 15$ U.S.C. $\S 78 \mathrm{p}(\mathrm{b})$ (2006). Moreover, it is possible that a federal court could assume supplemental jurisdiction over a state law derivative action, but it would likely be dismissed if the class is not certified since the plaintiffs would likely drop their direct claims that arise under federal law. It does not matter to the thesis here whether the corporate claim arises under state law or federal law. All that matters is that there is a claim.

49. It is no response to this analysis that stock prices might not behave as expected-for example that the derivative recovery might not result in a dollar-for-dollar increase in the market capitalization of the company.

50 . If the class consists of $30 \%$ of the shares, a $35 \%$ decrease in price (from $\$ 20$ to $\$ 13$ ) becomes a $50 \%$ decrease in price because of feedback. See formulas and explanation in Appendix infra. 


\section{Scenario II}

If the derivative action is litigated first - and we assume that a class action will follow - the corporation recovers $\$ 5$ million and stock price climbs back to $\$ 15$. The class then recovers $\$ 1.5$ million from the corporation - which the corporation effectively pays out of its recovery. And stock price drops back to $\$ 13.50$. That arguably would give rise to another derivative action. The bottom line is that the corporation must eventually recover enough from the individual wrongdoers so that stock price will finally settle at $\$ 15$. Thus, if the corporation recovers $\$ 6.5$ million and pays $\$ 1.5$ million to the buyers, everyone ends up in the right place. ${ }^{51}$ The problem with this scenario is that the corporation recovers too much. The market price would never drop so much in the first place if the expectation was that the corporation would recover enough from the individual wrongdoers to eliminate all losses beyond the initial $\$ 5$. So it is not immediately clear how much the corporation should recover.

\section{Scenario III}

There is a third scenario that should also be considered. The second scenario-where the derivative action is litigated first-is roughly equivalent to a derivative action in which part of the recovery is paid to individual stockholders rather than to the corporation. But if that were really the remedy, the corporation would recover $\$ 2$ million and buyers would recover $\$ 1.5$ million-both from the individual wrongdoers. Stock price would still settle at $\$ 15$ - because of the elimination of feedbackwhich is exactly where it would have settled in the absence of any fraud. In other words, everyone ends up where they would have ended up but for the fraud. ${ }^{52}$

As these three scenarios show, the aggregate amount of damages paid depends on the order in which the claims are resolved. In the first scenario, the total payout is $\$ 8$ million. In the second scenario, the total payout is $\$ 6.5$ million. And in the third scenario, the total payout is $\$ 3.5$ million. In the first scenario, the buyers recover too much. In the second scenario, the corporation may recover too much. Just as in Goldilocks, the third scenario is just right.

Needless to say, the various price adjustments described here would happen more or less instantaneously as the market processes the

51. It is not clear that the corporation could legally distribute part of the recovery to the buyers and to the exclusion of other holders since any such distribution might be seen as a non pro rata dividend.

52. For the sake of completeness, in the absence of recovery by the corporation, the buyers would suffer a $\$ 7$ loss per share and would thus recover $\$ 2.1$ million. 
possibilities and probabilities. But how the market reacts depends in large part on what the law is. As the law currently stands, market price should drop to $\$ 10$. But if the market expected the third scenario to ensue, it would presumably react quite differently.

There is a possible paradox lurking here. If the market expects that a class action will follow from corrective disclosure, then one might think that the drop in the market price would be mitigated somewhat by the prospect of recovery. Not so. With a class action remedy, the recovery goes to the buyer (even if the buyer later sells his stock). So there is no opportunity for arbitrage and no reason for the price to reflect the prospect of recovery. ${ }^{53}$ The effect on price is as if the stock has gone ex dividend. On the other hand, in a derivative action, the recovery goes to the corporation. So if the market expects corrective disclosure to be followed by a derivative action, the price decrease is likely to be somewhat muted by the prospect of the corporation's ultimate recovery. The bottom line is that price is not likely to drop as much as one would expect, which would decrease the ultimate recovery. Finally, if for some reason the market expects a derivative action in which individual buyers - but not the corporation-recover from individual wrongdoers, then presumably feedback will be eliminated, but there is no reason to expect any mitigating effect. $^{54}$

It is difficult to see how a court could choose to resolve a purported class action other than under the third scenario. If all of the claims can be satisfied with a smaller payment, presumably a court would so conduct the litigation. $^{55}$ To be sure, the third scenario requires that the court order individual recovery in a derivative action. And there is some precedent for doing so in appropriate cases. ${ }^{56}$

53. On the other hand, market price might not be affected at all (other than to reflect a fundamental decrease in value) if the market does not think that a meritorious class action will follow. Even if at first the market reacts to the prospect of a meritorious class action, stock price might recover somewhat if it later appears that the action will be dismissed. Needless to say, these possibilities complicate any empirical analysis of the price effect of class actions.

54. This assumes that buyers would recover even if they have sold following corrective disclosure, even though it is not clear that they have standing to do so, since Rule 23.1 of the Federal Rules of Civil Procedure requires that a derivative plaintiff remain a stockholder throughout the derivative action. To be sure, this rule may apply only to a representative plaintiff. But the rule is not at all clear on this point. Needless to say, in the real world stockholders will continue to trade during the pendency of the derivative action. So this may be another reason why only the corporation should recover. Diversified investors are unlikely to care much since they are just as likely to buy into a recovery as to miss one because they sold.

55. See Perlman v. Feldmann, 219 F.2d 173, 178 (2d Cir. 1955) (ordering individual recovery in part because aggregate award would be smaller).

56. There is substantial authority for individual recovery in a derivative action in appropriate cases. AM. LAW InSt., PRINCIPLES OF CORP. GOvernance § 7.18(e) (1994). 
To be clear, in a derivative action-even one with individual recovery-the corporation is the real plaintiff. The corporation recovers. Since the individual wrongdoers pay, there is no feedback and no reason for any stockholder to object to the compensation received by others as long as everyone is compensated in full. But to be realistic, full compensation is unlikely even though the aggregate recovery will almost certainly be smaller under the third scenario than it would be under the first scenario - the existing regime.

Thus, the question is, how should the recovery be distributed if there is not enough to satisfy all claims? The answer is that corporate claims should be satisfied first. Individual claims should be paid only if corporate claims are paid in full. There are several good reasons for this result.

First, since individual recovery is an extraordinary remedy, a court is not likely to opt for such a remedy unless there are excess funds available. Admittedly, this is a technical and lawyerly argument that has little to do with the merits. Nevertheless, both the federal courts and the Delaware courts have expressed clear hostility to individual recovery.

Second, one gets more bang for the buck with corporate recovery as opposed to individual recovery. As noted above, if a court in a derivative action orders individual recovery without corporate recovery, the buyers in the Duff example must be paid $\$ 2.1$ million to be fully compensated, whereas their claim is just $\$ 1.5$ million if the corporation first recovers $\$ 2$ million through a derivative action.

Third, if buyers get paid ahead of corporate claims, intra-class conflicts can arise. For example, if Duff buyers were to recover \$2.1 million while the corporation got zero, there will be a significant number of buyer-holders who would lose more from the lack of a derivative action than they would gain from individual recovery. To be specific, any buyer who bought less than $22 \%$ of his shares during the fraud period would lose more from the lack of corporate recovery than she gains from individual

See, e.g., Perlman, 219 F.2d at 178; see also Bangor Punta Operations, Inc. v. Bangor \& Aroostook R.R. Co., 417 U.S. 703, 714-18 (1974) (discussing the possibility of individual recovery); Vine v. Beneficial Fin. Co., 374 F.2d 627 (2d Cir. 1967). But the Delaware courts have been quite hostile to the idea. See Bokat v. Getty Oil Co., 262 A.2d 246, 250 (Del. 1970) (expressly rejecting Perlman as precedent); Keenan v. Eshleman, 2 A.2d 904 (Del. 1938). But see Audio Visual Xperts, Inc. v. Walker, No. 17261-NC, 2000 WL 222152, at *3 (Del. Ch. 2000) (holding that a Pennsylvania court would likely permit individual recovery in a derivative action involving a closely held corporation). In practice, individual recovery has been limited to situations in which wrongdoers would otherwise recover for their own wrongdoing or where some stockholders would enjoy a windfall because of the award. Incidentally, it will almost always be the case that some stockholders enjoy a windfall. Although the representative plaintiff in a derivative action must have held shares at the time of the wrong and must continue to hold shares until judgment, there is nothing to stop other stockholders from trading. Indeed, there is every reason to expect arbitrage in connection with the prospect of a derivative recovery. 
recovery. ${ }^{57}$ To be sure, this conflict is not as significant as the one generated by a traditional class action, but it is real nonetheless. No one should object, and no conflict should arise, if everyone is made whole. But if individual recovery depletes the funds available for settlement, some buyer-holders will object. Indeed, the courts have cited precisely this consideration in favoring derivative actions over class actions. To be specific, when faced with a claim by an individual stockholder under circumstances in which other stockholders have been harmed in the same way, courts have held that the claim should proceed as a derivative action rather than a direct action since to permit one stockholder to recover would effectively harm the other stockholders who also have claims. ${ }^{58}$

Fourth, one could argue that any payment to individual buyers amounts to an illegal non-pro-rata dividend if other stockholders would be left with shares worth less than they would have been worth in the absence of the fraud. Although individual recovery presumably would be ordered by a court, a court is unlikely to issue any such order other than in the context of a settlement to which the corporation itself is a party. But the fact remains that a derivative recovery belongs to the corporation in the first instance. And any use of corporate funds to benefit some stockholders to the detriment and exclusion of others is contrary to law whether ordered by a court or as a matter of action by the board of directors. ${ }^{59}$ Indeed, the same is true even if the corporation is made whole, which may explain why the Delaware courts have been so hostile to individual recovery.

Finally, as I argue above and further below, buyers need no remedy if they are diversified. With respect to undiversified investors, if they are left in the same position as if there had been no fraud, it is difficult to see why they should recover because of the bad luck of buying a stock that was about to fall.

57. Again, average annual turnover for Vanguard index funds is about $14 \%$. And (coincidentally) index funds account for about $14 \%$ of all equity mutual funds (by aggregate value). InVESTMENT COMPANY InstituTE, supra note 19, at 33.

58. See Smith v. Waste Mgmt., Inc., 407 F.3d 381, 384-85 (5th Cir. 2005) (holding that the misrepresentations at issue harmed the corporation as a whole, and thus a direct suit was not the proper avenue for relief); Shirvanian v. DeFrates, 161 S.W.3d 102, 110 (Tex. App. 2004) (finding that misrepresentations at issue constituted misuse of corporate assets and thus the proper claim is derivative); see also Cowin v. Bresler, 741 F.2d 410, 414 (D.C. Cir. 1984) ("Requiring derivative enforcement of claims belonging in the first instance to the corporation also prevents an individual shareholder from incurring a benefit at the expense of other shareholders similarly situated.").

59. See Sinclair Oil Corp. v. Levien, 280 A.2d 717, 720 (Del. 1971) (holding that selfdealing occurs when a parent corporation causes subsidiary to act in some way that benefits the parent, and disadvantages the minority shareholders). But see James J. Park, Shareholder Compensation as Dividend, 108 MicH. L. REV. 323, 324-27 (2009) (arguing that payment to some shareholders while excluding others can be warranted). 
Needless to say, an undiversified investor will likely object to the approach described above. To be sure, an investor who favors a class action might not be opposed in principle to a derivative action as long as his total recovery is equal to what he would recover under a class actionas long as the total of his individual recovery together with the increase in the value of his stock is equal to the total recovery he would have enjoyed with a class action alone. But given the very real possibility that buyers might not get paid at all if the corporation must first recover in full, it seems likely that many buyers would prefer to have their representative plaintiff seek the maximum possible class recovery even if there is some chance that everyone could be made whole by derivative recovery. In other words, an undiversified investor would presumably favor the first scenario in which aggregate damages are maximized. ${ }^{60}$

There is another possibly more important reason why some investors - or their lawyers - might favor a class action over a derivative action: Since damages are maximized in a class action, class action lawyers can command bigger fees than derivative action lawyers. This may also explain why, in practice, class actions tend to be emphasized and derivative actions are typically settled with nonmonetary governance reforms, as well as why derivative lawyers might go along with the arrangement. In short, it may be that a share of the fee from a class action is more than the fee would be from derivative action-and enough more that the derivative lawyer does better from a financial standpoint by playing second fiddle rather than lead guitar. To be sure, a derivative action is a risky undertaking in that the corporation may take over control of the litigation. Still, it is not unfair to suggest that class action lawyers effectively bribe derivative lawyers to take a fall. ${ }^{61}$

60. It may also be a subtle advantage that the class action depletes the insurance pot and leaves nothing for derivative recovery. Again, if the corporation gets a monetary recovery, it should reduce the class recovery.

61. This story is consistent with recent controversies about law firms paying buyers to serve as class action plaintiffs (which led to the indictment of William Lerach, Melvyn Weiss, and others). See Richard A. Booth, Why Pay a Fraud Plaintiff to Sue?, WASH. Post, June 26, 2006, http://www.washingtonpost.com/wp-dyn/content/article/2006/06/25/AR 2006062500527.html (arguing that often times plaintiffs are paid to join the class action because otherwise they have nothing to gain). Indeed, this practice suggests that many individual investors may in fact be neutral about class actions. To be fair, it can be quite time-consuming to serve as a representative plaintiff. And indeed PSLRA permits representative plaintiffs to be compensated for expenses including lost wages. On the other hand, if a law firm must retain an individual investor to have a client at the ready when fraud happens, the investor must be quite well diversified. This suggests that the typical representative plaintiff is not likely to be a good representative for the undiversified investors who should most favor class actions. The flap over paid plaintiffs has arguably led to another dubious practice. Although PSLRA requires that the class member with the largest claim be named the representative plaintiff (assuming he wants the job), the position goes to public and union pension plans in an unusually large proportion of cases. See 2009 
Yet another practical factor that may favor class actions over derivative actions is insurance. Again, buyer claims are typically paid by insurance. Although director and officer $(\mathrm{D} \& \mathrm{O})$ policies may cover some derivative claims, it would be odd for the insurance company to pay buyers to settle the class claim against the corporation and then to pay the corporation to settle its derivative claim against the individual wrongdoers. At the very least, the insurance company might seek to net the corporate recovery against the buyer recovery. Indeed, it is somewhat odd for the insurance company to pay the corporation at all: If the corporation that bought the insurance also stands to recover thereunder, presumably the corporation will argue for the biggest claim possible.

The obvious solution is to divorce D\&O coverage from the corporation's general liability coverage. (Incidentally, this would also address the insurance depletion problem discussed above.) Indeed, it is arguable that directors and officers should pay for their own insurance. At the very least, $\mathrm{D} \& \mathrm{O}$ insurance should be obtained from a separate carrier and should be treated as a compensation expense.

Finally, yet another factor that discourages derivative actions in practice is that defendant corporations may prefer class actions. A derivative action effectively pits a corporation against its own directors and officers, both of whom must be separately represented by their own attorneys. In contrast, in a class action the defendant corporation typically runs the defense even though the insurance company presumably could assume control if it insisted on doing so. In a class action, the corporation and its directors and officers can circle the wagons and present a unified defense. They may even be able to avoid addressing some questions about the potential liability of individual wrongdoers on the theory that it is irrelevant to assign individual blame if the corporation pays anyway. ${ }^{62}$

The bottom line is that securities litigation is riddled with market failures that effectively prevent the parties from reaching the most efficient outcome possible.

REVIEW AND ANALYSIS, supra note 36, at 11 (finding that derivative actions tend to have public pension plans serving as lead plaintiffs). One possible explanation for the activity of public pension plans is that law firms can effectively compensate such plaintiffs by making contributions to the campaigns of the officials who can influence fund decisions. Similar motivations may explain the activity of union pension plans. But unions may also be motivated by the possibility of influence over employment practices. It should be noted that institutions serve as lead plaintiffs in about $65 \%$ of cases. And when a pension plan serves as a lead plaintiff, settlements tend to be higher. Such cases are also more likely to be accompanied by a derivative action. Id. at 10-11.

62. On the other hand, PSLRA requires that the jury or the court determine the proportionate liability of anyone claimed to have caused or contributed to the loss incurred by the plaintiff apparently irrespective of whether any such person is a defendant in the action. See 15 U.S.C. § 78u-4(f) (2010) (providing for the proportionate liability scheme). 
To be sure one might object to the foregoing analysis as contrary to private ordering: Why should we prevent the parties from settling on any terms to which they can agree? So it seems a bit artificial to focus in such detail on who pays whom in what order. Moreover, since the settlement is almost always paid wholly by insurance, who is to say that practice is not consistent with the investor interests anyway? Presumably, we can trust the parties to work out an agreement that is as fair as it can be. In other words, the objection is that the law may be wrong, but in practice it does not matter. (While the French might object that it is not good enough for a solution to work in practice if it does not also work in theory, the common law tradition tends to ignore such niceties.)

The answer is that the parties are not in fact free to settle however they might agree. Whether the action is litigated as a class action or a derivative action, the court must approve any settlement. In practice, this means that the merits of the case are effectively litigated in the context of the court's potential approval of the settlement. ${ }^{63}$ Thus, the court must decide whether the settlement is fair and in doing so must consider the strength of the claims of the various parties. The obvious rationale for this rule is that these are representative actions and the rights of absent parties hang in the balance. Accordingly, the courts have-and should exercise-broad discretion in the management of securities litigation. ${ }^{64}$

\section{B. Restitution}

There is another potential source of derivative recovery. If directors, officers, or other agents of the defendant company engage in insider trading or other forms of misappropriation so as to profit from the bad news that

63. For a good example, see In re Cendant Corp. Sec. Litig., 109 F. Supp. 2d 235, 254 55 (D.N.J. 2000) (discussing settlement of class claims and objections of derivative plaintiffs thereto); In re Cendant Corp. Sec. Litig., 109 F. Supp. 2d 235, $246-54$ (D.N.J. 2000) (discussing derivative claims in detail and suggesting that corporation might be able to recover from its officers and agents as a result of losses suffered from an improvident settlement of a securities fraud class action). See also In re Cendant Corp. Litig., 264 F.3d 201, 217-21 (3d Cir. 2001) (reviewing settlement as a whole). The Cendant case is somewhat complicated by the fact that it included claims under the 1933 Act.

64. One might object that the foregoing analysis assumes first that everyone involved recovers $100 \%$ of the loss suffered (in concluding that the third scenario is optimal) and then assumes that it is unlikely that $100 \%$ of claims will be satisfied (in concluding that corporate claims should be paid first). There is no genuine contradiction here. It is important to consider how the law would work under ideal circumstances in thinking about what the rules should be. Even though securities fraud class actions almost always settle for something less than $100 \%$ of the claim, it is important to get the rules right since the rules determine the strength of the claim. In other words, it does not matter that cases are never litigated all the way to a resolution. We still need to get the rules right so that the parties will be able to negotiate with each other having some sense of who would win what or lose what if an agreement cannot be reached. See infra note 110 and accompanying text. 
triggers the securities litigation, the company may have a claim for restitution in addition to the other claims discussed above. ${ }^{65}$ It is not clear that such insider gains contribute much (if anything) to investor losses (although it is possible that insider selling may effectively increase public float and cause some slight additional downward pressure on share price) ${ }^{66}$ On the other hand, insider trading may be a factor in any reputational harm. And indeed, insider trading has been cited by the courts as evidence of scienter. ${ }^{67}$ In any event, under well-established principles of agency law insider gains can clearly be recovered by the company as secret profits. ${ }^{68}$ This claim is clearly one that belongs to the defendant company because

65. See Pfeiffer v. Toll, 989 A.2d 683, 704-08 (Del. Ch. 2010), abrogated by Kahn v. Kolberg Kravis Roberts \& Co., L.P., 23 A.3d 831, 836-40 (Del. 2011); Brophy v. Cities Serv. Co., 70 A.2d 5, 7-8 (Del. Ch. 1949) (recognizing the right of a Delaware corporation to recover from its fiduciaries for harm caused by insider trading). See also United States v. O'Hagan, 521 U.S. 642, 654 (1997) (stating that a fiduciary who engages in insider trading defrauds principal in connection with the purchase or sale of securities by misappropriating principal's information for personal gain); Moss v. Morgan Stanley, Inc., 719 F.2d 5, 15-16 (2d Cir. 1983) (deciding that a counterparty to insider trade has no claim where violation is based on duty that runs to principal whose information was misappropriated). See generally A.L.I., PRINCIPLES OF CORP. GOVERNANCE $§ 5.04$ (1994) (providing a statutory basis for the rule that executives or board members cannot improperly use corporate property for their own benefit). Ironically, there is some doubt about whether state law claims for disgorgement continue to survive in the face of sweeping federal law that arguably occupies the field of insider trading (or indeed whether there ever was any claim for disgorgement under Delaware corporation law). But there seems to be no question that insider trading constitutes a breach of fiduciary duty and that consequential damages may be recovered. See In re Oracle Corp. Derivative Litig., 867 A.2d 904, 928 n.111 (Del. Ch. 2004) ("Notably, the abolition of Brophy would not preclude a recovery by the corporation for actual harm to itself caused by illicit insider trading by a fiduciary, but the existence and extent of such damage would have to be proven."); see also Freeman v. Decio, 584 F.2d 186, 192 (7th Cir. 1978) (holding that under Indiana law a derivative suit may not be maintained against corporate officers and directors to recover profits for alleged illegal trading of corporate stock on basis of material inside information); In re ORFA Sec. Litig., 654 F. Supp. 1449, 1455 (D.N.J. 1987) (holding that a derivative claim by a harmed corporation against officers on basis of insider trading stated cause of action under New Jersey law); Schein v. Chasen, 313 So. 2d 739, 746 (Fla. 1975) (holding that corporation may recover only if it suffered harm from insider trading). But see Diamond v. Oreamuno, 248 N.E.2d 910, 912 (N.Y. 1969) (holding that allegation of damage to corporation is not essential element of a derivative suit against a director for insider trading). See generally Douglas M. Branson, Choosing the Appropriate Default Rule-Insider Trading Under State Law, 45 ALA. L. REV. 753, 765-71 (1994) (arguing that under state law, liability for trading on inside information is significantly assigned).

66. Although there may be some slight further decrease in price that is attributable to insider gain, it is not clear that it is worthwhile to pursue it since the company is clearly entitled to recover the gain from the recipients on a theory of unjust enrichment.

67. See, e.g., Novak v. Kasaks, 216 F.3d 300, 312 (2d Cir. 2000) (finding that by trading on prohibited information, a culpable state of mind can be imputed to the offender).

68. See Restatement (ThIRD) OF AGency $\S \S 8.02,8.05$ (2006) (providing a statutory basis for the forfeiture of improperly derived gains by an agent). 
the duty is one that runs to the company. In other words, it is a derivative claim. Although this claim is likely to be relatively small compared to the total loss suffered by buyers and holders, it may nonetheless add some marginal amount to the potential derivative recovery so as to further reduce buyer claims. Thus, it provides an additional reason for a derivative action.

One possible problem with this claim is that federal law also provides for a direct claim by contemporaneous traders who would presumably also be members of any plaintiff class arising from the same set of events. ${ }^{69}$ This may also create a conflict within the plaintiff class-albeit a manageable one-between class members who should recover investment losses only and class members who should recover investment losses plus contemporaneous trading losses. But there is nothing in federal law to suggest that the cause of action for contemporaneous trading preempts the established state law claim that belongs to the company. ${ }^{70}$ Indeed, federal law expressly recognizes the claims of the corporation. First, although class claims for securities fraud must be litigated in federal court under the Securities Litigation Uniform Standards Act (SLUSA), SLUSA expressly preserves state court jurisdiction over derivative actions in a provision popularly known as the Delaware carve-out. ${ }^{71}$ Second, federal courts look to state law to determine whether there is any duty to disclose or abstain from trading under Rule 10b-5. ${ }^{72}$ Finally, the Securities Exchange Act

69. See Securities Exchange Act of 1934 § 20A, 15 U.S.C. § 78t-1 (2006) (explaining the details of the liability that may be attached to traders who engage in insider trading).

70. See LaSala v. Bordier et Cie, 519 F.3d 121, 137-42 (3d Cir. 2008) (holding that preempted claims under the Securities Litigation Uniform Standards Act did not prevent claims under Swiss law); Pfeiffer, 989 A.2d at 708 (denying the corporation's motion to dismiss shareholder's claim because the shareholder adequately pled demand futility and stated a claim for breach of duty of loyalty). If anything, it is the federal claim for contemporaneous trading that seems peculiar.

71. See Securities Exchange Act of $1934 \S 28(f), 15$ U.S.C. $\S 78 b b$ (2006). There are actually two (or three) such carve-outs in the section. One preserves actions relating to the purchase or sale of stock by the issuer and actions relating to stockholder voting and similar decisions (even though these actions may involve allegations of nondisclosure). The other carve-out preserves an exclusively derivative action brought by one or more stockholders on behalf of a corporation. It is the latter that is the focus here. It is somewhat troubling that this provision relates to an exclusively derivative action in that this modifier might suggest that a derivative action involving the possibility of individual recovery might not be exempted. On the other hand, such an action could always be tried in federal court.

72. See, e.g., United States v. O'Hagan, 521 U.S. 642, 665-66 (1997) (holding that the misappropriation theory could be applied to secure liability under the Securities Exchange Act based on state law); Dirks v. SEC, 463 U.S. 646 (1983) (showing that the Supreme Court based its holding on relevant state law to conclude that that petitioner did not owe a duty to abstain from insider trading); Santa Fe Indus., Inc. v. Green, 430 U.S. 462, 478-80 (1977) (demonstrating that the Supreme Court applied Delaware law in analyzing the shareholder's cause of action). Indeed, the SEC has established a procedure by which it may refer substantive questions of corporation law to state court. See, e.g., CA, Inc. v. AFSCME Emp. Pension Plan, 953 A.2d 227, 231-40 (Del. 2008) (outlining the SEC 
provides that in cases of short-swing trading-presumptive insider trading-by a director or officer or major stockholder, the issuer corporation may recover any profit or loss avoided. Indeed, the statute expressly provides that if the corporation fails to seek recovery, a stockholder may file a derivative action (although the action must be filed in federal court because of exclusive federal jurisdiction over claims arising under the 1934 Act). ${ }^{73}$

While there can be little doubt that federal law preserves the state law claims of the corporation outlined here, the implication is that individual defendants could be sued for the same claim twice. ${ }^{74}$ That may not be a problem in principle since federal law provides for a treble-the-gain fine for insider trading anyway. ${ }^{75}$ So why not four times the gain? Nevertheless,

procedure for solving issues based on corporate law in Delaware where the defendant corporation was incorporated). In addition, the SEC has been known to file amicus briefs in state court in cases in which the effect of its rules may depend on state law. See Moran v. Household Int'l, Inc., 490 A.2d 1059, 1078 (Del. Ch. 1985) (noting that the SEC submitted a Report of Recommendations in a prior case where state law was at issue).

73. See Securities Exchange Act of $1934 \S 16(b), 15$ U.S.C. $§ 78 p(b)$ (noting that any profit from the purchase and sale of security should be recoverable by the issuer within six months). It is also conceivable that the corporation may have a claim under Rule $10 \mathrm{~b}-5$ on the theory that the fraud caused a loss in the value of the corporation. See Goldberg v. Meridor, 567 F.2d 209, 218-19 (2d Cir. 1977) (holding that the plaintiff adequately stated a claim for loss of value due to misleading press releases).

74. See Pfeiffer, 989 A.2d at 708 (demonstrating that the court allowed the defendant to be sued for breach of duty of loyalty).

75. See Securities Exchange Act of $1934 \S 21$ A, 15 U.S.C. 78u-1 (2006) (explaining civil penalties imposed for insider trading). The treble-the-gain fine (TGF) was added first by the Insider Trading Sanctions Act of 1984 (ITSA) (as featured-and misnamed - in the movie Wall Street) and was later beefed up by the Insider Trading and Securities Fraud Enforcement Act of 1988 (ITSFEA). Insider Trading Sanctions Act of 1984, Pub. L. No. 98-376, 98 Stat. 1264 (1984) (current version at 15 U.S.C. $§ 78 u-1$ (2006)); Insider Trading and Securities Fraud Enforcement Act of 1988, Pub. L. No. 100-704, 102 Stat. 4677 (1988), (current version at 15 U.S.C. $\S 780$ (2006)). ITSFEA expanded the TGF to provide for the possibility of assessment against controlling persons who failed to institute adequate safeguards designed to prevent insider trading by officers, employees, and other controlled persons. ITSFEA also provided for the claim by contemporaneous traders but only to the extent of the gain (or loss avoided) by those engaging in insider trading. The TGF is retained by the SEC. ITSA and ITSFEA were designed to address the problem that mere disgorgement is no real disincentive for insider trading. If the only consequence is that one must give back the gain, there is no reason not to engage in insider trading (if one ignores the costs of defense and possible jail time). Moreover, there is little incentive for counterparties to sue if they can recover only a minute percentage of their loss. But if everyone who trades at the same time as insiders can recover their losses, the potential liability for insider trading would be massive. For good discussions of this problem, see Fridrich v. Bradford, 542 F.2d 307, 318-23 (6th Cir. 1976) (holding that based on current law, plaintiffs could not collect damages for losses caused by the insider third-party trading of the defendants) and Shapiro v. Merrill Lynch, Pierce, Fenner \& Smith, Inc., 495 F.2d 228, 230-31 (2d Cir. 1974) (holding that plaintiffs could collect damages for their losses due to the defendants' acts of insider trading). Overdeterrence can be as bad as 
the prospect of individual wrongdoers being sued twice for the same wrong is likely to give rise to conflicts between the class action and the derivative action. Presumably, the class representative will argue that the claim should belong to the class, and the derivative representative will argue that the claim should belong to the company. Indeed, class members who did not happen to trade contemporaneously with insiders may also favor treating these claims as derivative since they will benefit somewhat from any derivative recovery while any direct recovery will likely go to those individual class members who happened to trade at the same time as insiders. $^{76}$

underdeterrence since the threat of massive liability may discourage legitimate trading activity that keeps the market efficient. Needless to say, a standalone claim for contemporaneous trading holds little value for investors. In many cases, the gains from insider trading may not be enough even to motivate a class action lawyer to sue. And in most cases, the large number of investors who happen to buy at about the same time that insiders sell will so dilute the recovery of individual buyers that many would likely not even bother to claim their share of a settlement. Thus, it is not surprising that there are very few reported cases involving a claim for contemporaneous trading. In contrast, it seems much more sensible for the company to recover the ill-gotten gains of insiders in one lump sum than for individual investors to pursue pennies apiece for contemporaneous trading. On the other hand, one might argue that a direct claim for contemporaneous trading may be justified as a way of encouraging claims against individual wrongdoers since the damages in securities fraud class actions are usually paid wholly by the company (or the company's insurer). Still, it is somewhat troubling that ITSFEA provides that the corporation may be held liable for the insider trading of its agents in some circumstances since the essence of the argument here is that the claim is one that rightfully belongs to the corporation. Moreover, as noted above, federal law provides that the corporation recovers for shortswing trading - what one might call per se insider trading. See Securities Exchange Act of $1934 \S 16(\mathrm{~b}), 15$ U.S.C. $\S 78 \mathrm{p}$ (b) (2006) (requiring statutory insiders to disgorge profits from purchasing and selling company securities within a six-month period). In short, federal law relating to insider trading is hopelessly confused.

In addition to the above rationale, the claim for contemporaneous trading addresses the problem illustrated by Chiarella v. United States, 445 U.S. 222, 231-35 (1980) (holding that the corporation's employee did not owe shareholders a duty to disclose inside knowledge), and Moss v. Morgan Stanley, Inc., 719 F.2d 5, 14-15 (2d Cir. 1983) (holding that the shareholder failed to state a claim because he could not show that any of the defendants owed him a duty of disclosure), that the counterparty to an insider trade has no claim where the violation is based solely on a duty that runs to principal whose information was misappropriated. In other words, counterparties have no claim in circumstances in which third parties who have access to inside information derived from outside the company (such as information about a pending tender offer) use that information to trade in the stock of the target company. The claim for contemporaneous trading was largely born of Congressional frustration at its inability to come up with a definition for insider trading. In other words, the provision smacks of the need to do something for the sake of appearance. So Congress threw a bone to investors. Regrettably, it caused even more confusion in that it reinforced the misguided notion implicit in class actions that the way to address securities fraud is to provide for direct individual investor recovery.

76. It is worth asking how the law relating to securities fraud evolved into such a confused state. The answer is really quite simple. Under the 1933 Act, an investor who buys newly issued stock in a fraudulent offering is entitled to damages or rescission as 
against the issuer. Securities Act of $1933 \S \S 5,12,15$ U.S.C. $\S 77 E$ (2006). But the remedy is limited to investors who buy newly issued stock in which the company itself is (usually) the seller. In effect, the remedy is one of disgorgement. If the company is already publicly traded and makes an offering of additional stock, the remedy extends only to the newly issued stock. The buyer must be able to trace the stock he bought to the offering in order to have a remedy. See, e.g., In re Initial Pub. Offering Sec. Litig., 471 F.3d 24, 45 n.1 (2d Cir. 2006) (explaining that a plaintiff must show that its shares were a part of the offering in question marred by a defective registration statement). The problem is that an investor who buys on the secondary market may not be able to prove that his stock was part of the offering even though he may be able to show that he read and relied on the prospectus issued by the company. It seems unfair to deny a remedy to such an investor. Thus, the courts permitted such investors to recover under Rule 10b-5 if they were able to show the additional elements required thereunder. In other words, actions under Rule 10b-5 may have been seen largely as supplementary to actions under the 1933 Act under which only those who can trace their shares to a public offering have a remedy. Under Rule 10b-5, investors who bought already outstanding shares could also sue. 17 C.F.R. $\S 240.10 b-5$ (2012). (Never mind that the company might thereby pay out more than it raised in the offering). It was a small step from using Rule 10b-5 to supplement claims under the 1933 Act to permit investors to sue even in the absence of an offering if the company made some sort of false statement that affected market price. Moreover, when securities fraud class actions first developed in the 1960s, most stock was held by poorly diversified individual investors. Arguably, such investors needed the protections afforded by securities fraud class actions.

This is not to suggest that there is a problem with the 1933 Act. To the contrary, it makes perfect sense for investors who buy newly issued stock from the company itself to recover from the company in cases of fraud. In effect, the 1933 Act provides for disgorgement by issuers in cases in which they have effectively misappropriated capital from the market by false pretenses. Although the recovery reduces the aggregate value of the company, it does not give rise to feedback in the same way as an action under Rule 10b5 because recovery is limited to the proceeds of the offering. It merely returns the company to its financial status before the offering. But that does not mean that securities fraud class actions make sense and that the company should pay whether or not it benefits from the supposed fraud. Moreover, the 1933 Act makes sense even in a world of efficient markets and diversified investors. As the courts have noted, there is no efficient market in IPOs. But the 1933 Act is not premised on an efficient market. It is aimed at companies who gain access to the capital markets by fraud. To be clear, the ultimate problem with recognizing any direct action by buyers against the company is that the company pays. No one has suggested that we should require sellers to give back their gains. Thus, it is not clear that there should be any such remedy against the company. Again, the Supreme Court has never expressly approved the measure of damages nor indeed the idea that federal law implies that the company should pay in the absence of an offering. On the other hand, federal law has provided from the beginning that the corporation may recover short-swing gains from officers, directors, and major stockholders. In other words, the approach advocated here is wholly consistent with the general scheme of federal securities law, which seems to focus on a rescission and restitution as the primary remedies.

It is really quite extraordinary that Congress has legislated as much as it has in this area-which is not to mention the extraordinary number of Rule $10 b-5$ cases that have been decided by the Supreme Court. It is even more extraordinary that Congress has gone so far as to alter the rules of civil procedure just to deal with the litigation tactics that have evolved in connection with the particular subject matter of securities fraud. It may be that the large sums of money involved have attracted undue attention from the plaintiff bar. But it seems more likely that there is something about the law of securities fraud that is out of kilter. See 
To summarize this part of the argument, there is a fundamental conflict between the interests of diversified investors and the interests of undiversified investors. Undiversified investors are likely to favor class actions. Diversified investors are likely to oppose class actions and to favor derivative actions. Although undiversified investors would not object to a derivative action in principle, they might object because the derivative recovery would reduce the class recovery. In other words, each group opposes what the other favors. Investors who stand to gain more from a class action will want their representative plaintiff (and lawyer) to maximize their claim by downplaying or indeed ignoring any evidence of derivative claims. The remainder of investors will want a zealous derivative plaintiff (and lawyer) to maximize derivative claims.
\end{abstract}

\title{
III. CLASS ACTION REQUIREMENTS
}

Under Rule 23(a) of the Federal Rules of Civil Procedure (FRCP) a class action may be maintained only if:

(1) the class is so numerous that joinder of all members is impracticable; (2) there are questions of law or fact common to the class; (3) the claims or defenses of the representative parties are typical of the claims or defenses of the class; and (4) the representative parties will fairly and adequately protect the interests of the class. ${ }^{77}$

In addition, Rule 23(b)(3), which governs actions for damages, requires that:

$[T]$ he court finds that the questions of law or fact common to the members of the class predominate over any questions affecting only individual members, and that a class action is superior to other available methods for the fair and efficient adjudication of the controversy. The matters pertinent to the findings include: (A) the class members' interests in individually controlling the prosecution or defense of separate actions; (B) the extent and nature of any litigation concerning the controversy already begun by or against members of the class; (C) the desirability or undesirability of concentrating the litigation of the claims in the

Richard A. Booth, The Missing Link Between Insider Trading and Securities Fraud, $2 \mathrm{~J}$. BUS. TECH. L. 185, 195-98 (2007) (arguing that federal securities law does not adequately cover many ways that insider trading can be conducted).

77. FED. R. CIV. P. 23(a) (emphasis added). 
particular forum; and (D) the likely difficulties in managing a class action. ${ }^{78}$

Rule 23(c) requires that an action must be certified as a class action at an early practicable time. ${ }^{79}$ That is, the trial court must determine that the action is an appropriate one to be handled as a class action. If not, the action reverts to an individual action on behalf of the named plaintiffs.

Finally, Rule 23(d) provides that in the conduct of a class action, "the court may issue orders that: (A) determine the course of proceedings or prescribe measures to prevent undue repetition or complication in presenting evidence or argument." $\$ 0$

Rule 23 presupposes that the court will determine whether the claims are direct or derivative, and thus whether the Rule applies at all. In other words, the question whether a claim is properly characterized as a direct class claim, a derivative claim, or some combination thereof comes before any question about whether an action may be maintained as a class action under Rule 23. That the court must answer that question is implicit in the certification requirement of Rule 23(c). There is no doubt that the court has the power to decide whether an action is direct or derivative. The fact that the parties have characterized the action as direct does not make it so. ${ }^{81}$

Moreover, if the court decides that the claims asserted include both direct and derivative claims, it is also implicit in Rule 23 that it is up to the court to determine the order in which the claims will be resolved. ${ }^{82}$

As noted above, there are compelling reasons why derivative claims should be decided first. A derivative recovery will reduce any direct recovery, whereas recovery directly against the company will increase a derivative recovery. Thus, it is impossible to know the correct amount of a direct claim until the derivative claim has been determined.

Assuming (for the sake of argument) that the court determines that there are direct claims that may be litigated in a class action, the court must then determine that class action status is appropriate. In practice, the courts

78. Id. at 23(b)(3) (emphasis added).

79. Id. at 23(c).

80. Id. at $23(\mathrm{~d})(1)(\mathrm{A})$.

81. See Bangor Punta Operations, Inc. v. Bangor \& Aroostook R.R. Co., 417 U.S. 703, 713 (1974) (holding that an entity who purchased $98.3 \%$ of stock from a corporation and alleging no fraud has no standing in equity to maintain this action for alleged corporate mismanagement); and Tooley v. Donaldson, Lufkin, \& Jenrette, Inc., 845 A.2d 1031, 1033 (Del. 2004) (holding that plaintiffs lost their standing to bring action when they tendered their shares in connection with a merger). Indeed, where a claim may be pursued as a derivative action, it should be pursued as a derivative action. See supra note 54 and accompanying text.

82. Federal Rule of Civil Procedure Rule 23(b)(3)(D) states that the court must consider the difficulties likely to be encountered in the management of a class action. FED. R. CIV. P. 23(b)(3)(d). Moreover, Rule 23(d) provides that the court has the power to issue such orders as are necessary to manage the action. 
have not strictly applied the requirements of Rule 23. But, the Second Circuit recently ruled that a trial court must determine that all of the requirements for a class action have been met in order to certify the class. ${ }^{83}$ It is not enough for the trial court to find that there has been some showing that the action satisfies the standards set forth in Rule 23. Rather, the court must find by a preponderance of the evidence that the action satisfies the requirements of Rule 23. ${ }^{84}$ As the Second Circuit stated:

A district judge is to assess all of the relevant evidence admitted at the class certification stage and determine whether each Rule 23 requirement has been met, just as the judge would resolve a dispute about any other threshold prerequisite for continuing a lawsuit. Finally, we decline to follow the dictum in Heerwagen suggesting that a district judge may not weigh conflicting evidence and determine the existence of a Rule 23 requirement just because that requirement is identical to an issue on the merits. ${ }^{85}$

In other words, courts must take seriously the requirements of Rule 23 in deciding whether an action may proceed as a class action. ${ }^{86}$

Few securities fraud actions are likely to pass muster. The conflict of interests between diversified investors and undiversified investors and among various diversified investors who follow various trading strategies poses a serious problem for class action certification. Indeed, the conflict is so fundamental (and unmanageable) that the courts should decline to certify securities fraud class actions that seek damages on behalf of individual investors. First, given that there will always be a substantial number of class members opposed to certification, it is simply impossible for anyone to qualify as an adequate class representative. Second, the differing interests of diversified and undiversified investors give rise to individual questions of fact - reliance in particular - that predominate over common questions. Third, since part of the claim in any meritorious class action is likely to be derivative, a derivative action is clearly superior to a class action.

83. In re Initial Pub. Offering Sec. Litig. 471 F.3d 24 (2d Cir. 2006).

84. Id. at 42. See also Oscar Private Equity Invs. v. Allegiance Telecom, Inc., 487 F.3d 261, 264 (5th Cir. 2007) ("The class certification determination rests within the sound determination of the trial court . . .."); Regents of the Univ. of Cal. v. Credit Suisse First Boston (USA), Inc., 482 F.3d 372, 393-94 (5th Cir. 2007) (reversing a class certification due to lack of classwide reliance on misleading information).

85. In re IPO Sec. Litig., 471 F.3d at 42.

86. Id. 


\section{A. Adequate Representation}

One of the four requirements that must be met in all class actions is that the named plaintiff(s) will fairly and adequately protect the interests of the class. ${ }^{87}$ Given their fundamentally conflicting interests, it is impossible for an undiversified stock-picking investor adequately to represent a diversified portfolio-balancing investor. ${ }^{88}$ A diversified portfolio-balancing investor would not likely ever file a class action in the first place, but he might well file a derivative action. On the other hand, an undiversified stock-picking investor would be quick to file a class action and probably would oppose a derivative action if it were to take precedence over the class action. ${ }^{89}$ These conflicts are doubly troubling because the derivative action is in effect a class action on behalf of all stockholders, whereas the class action is an action on behalf of buyers only. Some of the stockholders and buyers would object to certification of the class action but favor the prosecution of the derivative action.

The law is clear that no one can represent both of these groups. The courts have recognized that one individual cannot serve as the representative plaintiff in both a direct class action and a derivative action because the plaintiff's interest in maximizing his individual recovery is likely to conflict with his interest in maximizing the derivative recovery that goes to the company. ${ }^{90}$ Thus, the conflict between diversified and

87. FeD. R. Civ. P. 23(a)(4).

88. As discussed above, there are a variety of investor types that may fall between these two extremes, and it may be difficult to draw the line between those who benefit from a class action and those for whom the class action is a net detriment. Still, for present purposes it is enough to consider these two polar types of investors as likely to be in any plaintiff class. Thus, the discussion here focuses on the conflicting interests of these two archetypes and does not explore in any detail the conflicts that might arise between other possible investor types.

89. See Fed. RulE. Civ. P. 23.1, which governs derivative actions. It also requires that the named plaintiff also be found to be an adequate representative of the corporation.

90. See Zarowitz v. BankAmerica Corp., 866 F.2d 1164, 1166 (9th Cir. 1989) (wherein plaintiff could not serve as derivative plaintiff where his interest in increasing the value of his stock "through a larger derivative suit recovery [was] dwarfed by his interest in pursuing his litigation with the Bank"); Owen v. Modern Diversified Indus., Inc., 643 F.2d 441, 443 (6th Cir. 1981) (wherein plaintiff could not serve as derivative plaintiff where there was "a strong possibility that [the] derivative action would be used merely as a device to obtain leverage" in plaintiff's individual suit); Davis v. Comed, Inc., 619 F.2d 588, 593-94 (6th Cir. 1980) (considering the plaintiff's relationship and familiarity with the class litigation); Ryan v. Aetna Life Ins. Co., 765 F. Supp. 133, 136-37 (S.D.N.Y. 1991) (holding that a minority shareholder who sought to bring derivative suit on behalf of corporation and, simultaneously, class action against corporation and other defendants was subject to conflict of interest which rendered him unable to fairly and adequately represent interest of shareholders); Kamerman v. Steinberg, 113 F.R.D. 511, 515-16 (S.D.N.Y. 1986) (class certification denied where plaintiffs also brought derivative claims); Horowitz v. Pownall, 582 F. Supp. 665, 666 (D. Md. 1984) (finding conflict where "the proposed class and 
undiversified investors is fundamentally different from the somewhat worrisome possibility that a representative plaintiff might seek to shift around the damages within the class period. ${ }^{91}$ Rather, the conflict is between an investor class that would want the action to go forward and an investor class that would prefer to see it dismissed or converted into a derivative action.

The Supreme Court long ago ruled unequivocally that a representative plaintiff who has an interest in asserting a claim cannot represent a party whose interests may be opposed to those of the representative plaintiff. In Hansberry v. Lee, ${ }^{92}$ the plaintiff sought an injunction seeking to prohibit

plaintiff would be in direct competition with each other for the damages that the directors and officers would be required to pay in compensation for their illegal actions"); Petersen v. Federated Dev. Co., 416 F. Supp. 466, 475 n.6 (S.D.N.Y. 1976) (assumption that plaintiff bringing individual and derivative claims cannot fairly represent shareholders); Caan v. Kane-Miller Corp., No. 71 Civ. 878 (WCC), 1974 U.S. Dist. LEXIS 13019, at *7 (S.D.N.Y. 1974) (individual and derivative actions may not be maintained simultaneously); Ruggiero v. American Bioculture, Inc., 56 F.R.D. 93, 94-95 (S.D.N.Y. 1972) (holding that class and derivative actions may not be pursued simultaneously). See also In re Pacific Enters. Sec. Litig., 47 F.3d 373, 378 (9th Cir. 1995) (expressing concern in connection with approval of settlement about Milberg Weiss law firm's dual representation of class and derivative plaintiffs). But see Mayer v. Dev. Corp. of America, 396 F. Supp. 917, 930-31 (D. Del. 1975) (individual action against corporation is not absolute bar to derivative action). Delaware courts have had little trouble with this conflict in actions arising under state corporation law. Compare Colonial Sec. Corp. v. Allen, C.A. No. 6778, 1983 Del. Ch. LEXIS 393, at*12-13 (Del. Ch. 1983), and Youngman v. Tahmoush, 457 A.2d 376, 380 (Del. Ch. 1983) ("The fact that the plaintiff may have interests which go beyond the interests of the class, but are at least co-extensive with the class interest, will not defeat his serving as a representative of the class.") with Scopas Tech. Co. v. Lord, No. 7559, 1984 WL 8266, at *6-7 (interest in his personal claims outweighed his interest in pursuing the derivative action with the same vigor as the personal claims).

91. Traditionally, the courts have been unreceptive to the argument that a representative plaintiff might seek to undermine the claims of some class members. See Freeland v. Iridium World Commc'ns, Ltd., 233 F.R.D. 40, 48 (D.D.C. 2006) (holding that plaintiff who sold his stock before the end of class period did not disqualify him as class representative), citing In re Gaming Lottery Sec. Litig., 58 F. Supp. 2d 62, 70 (S.D.N.Y. 1999) (holding that conflict of interest did not represent a valid reason for refusing to certify a class); see also In re Baan Co. Sec. Litig., No. 1:98cv2465 (ESH), 2002 U.S. Dist. LEXIS 27875 (D.D.C. 2002); In re Oxford Health Plans, Inc. Sec. Litig., 191 F.R.D. 369, 377-78 (S.D.N.Y. 2000) (holding that potential conflicts in the proposed class were not fatal to certification). But see In re Seagate Tech. II Sec. Litig., 843 F. Supp. 1341, 1344 (N.D. Cal. 1994) (finding that the representative plaintiff had divergent interests from the plaintiff class). In most cases, it is difficult to see how one subgroup would gain from a loss by another subgroup. At worst, the representative plaintiff might seek to emphasize the losses suffered during a particular part of the class period, increasing damages for some investors and decreasing damages for others depending on when they bought the subject stock. However, plaintiff lawyers will seek to maximize aggregate damages. Therefore, the problem largely takes care of itself. The conflict between diversified and undiversified investors is different.

92. 311 U.S. 32 (1940). 
defendants from owning and occupying real property in violation of a restrictive covenant. The covenant had been upheld as valid in a previous decision by the Illinois Supreme Court in an action brought by similarly situated landowners who sought to enforce it. In Hansberry, the Illinois Supreme Court ruled that its previous decision was a "class" or "representative" action that had determined the rights of other members of the class - similarly situated landowners - and was thus res judicata in the later action. The United States Supreme Court reversed the decision of the Illinois court on due process grounds, ruling that plaintiffs who sought to enforce the covenant could not be said to have represented the interests of parties who sought to challenge the covenant. As the Court stated:

Those who sought to secure [the benefits of the covenant] by enforcing it could not be said to be in the same class with or represent those whose interest was in resisting performance .... If those who thus seek to secure the benefits of the agreement were rightly regarded by the state Supreme Court as constituting a class, it is evident that those signers or their successors who are interested in challenging the validity of the agreement and resisting its performance are not of the same class in the sense that their interests are identical so that any group who had elected to enforce rights conferred by the agreement could be said to be acting in the interest of any others who were free to deny its obligation.

Because of the dual and potentially conflicting interests of those who are putative parties to the agreement in compelling or resisting its performance, it is impossible to say, solely because they are parties to it, that any two of them are of the same class. Nor without more, and with the due regard for the protection of the rights of absent parties which due process exacts, can some be permitted to stand in judgment for all.

It is one thing to say that some members of a class may represent other members in a litigation where the sole and common interest of the class in the litigation, is either to assert a common right or to challenge an asserted obligation. It is quite another to hold that all those who are free alternatively either to assert rights or to challenge them are of a single class, so that any group, merely because it is of the class so constituted, may be deemed adequately to represent any others of the class in litigating their interests in either alternative. Such a selection of representatives for purposes of litigation, whose substantial interests are not necessarily or even probably the same as those whom they are deemed to represent, does not afford that 
protection to absent parties which due process requires. ${ }^{93}$

It follows that where some members of the class would be opposed to the class action, the action cannot be certified as a class action. ${ }^{94}$

In response, a named plaintiff might argue that he seeks only to represent the interests of buyers. In other words, he might argue that he seeks only to serve the interests of buyer-holders as buyers and that he does not seek to represent them as holders. Moreover, he might further argue that while holders might object to the class action and favor a derivative action, they have no standing to sue. Or the named plaintiff might try to define the class as one comprising only buyers who bought enough of a fraud-affected stock that they would recover more from the class action than they would lose as holders. Indeed, the plaintiff might seek to exclude all buyer-holders simply for the sake of simplicity. ${ }^{95}$

To argue that the named plaintiff seeks only to represent investors who favor the class action is for the procedural tail to wage the substantive dog. At some point, efforts to gerrymander the definition of the class must run into due process limits. Rule 23 requires that the named plaintiff represent the interests of the plaintiff class. ${ }^{96}$ Indeed, the courts have held that a representative plaintiff is a fiduciary. ${ }^{97}$ It would seem to follow that the named plaintiff may not ignore the interests of potential class members by the simple expedient of excluding them from the class. So it is difficult to see how a class action may satisfy the requirements of due process if the class is defined in such a way as to exclude class members with

93. Id. at 44-45 (citations omitted) (emphasis added).

94. Admittedly, Hansberry is distinguishable in that the plaintiff essentially sought to represent absent parties who presumably would have argued the other side of the controversy. In a securities fraud class action, those opposed to the class action do not seek to disprove the case of those who favor the class action. Rather, they simply oppose the assertion of the class claim at all.

95. The named plaintiff might also argue that the objections of buyer-holders are part of a collusive scheme involving holders who have no standing to sue. Thus, it might be argued that a court should not consider the holder-interests of buyer-holders in determining whether the class action should proceed. In other words, we should consider the interests of buyerholders only as if they were buyers and ignoring the fact that they are also holders. Again, it does no good for the plaintiff to argue that class members may vote with their feet by opting out of the class action. Many buyer-holders who would object to the class action and favor a derivative action instead would still not opt out of the class action if it goes forward, because to do so would be to forfeit the compensation to which they would be entitled and would increase their effective loss. If the action is successful, those who opt out effectively pay those who remain in the action. But as holders they receive none of the benefit. In the end, the burden is on the named plaintiff to define the class in a way that permits class members to be manageably ascertained. See In re Initial Pub. Offering Sec. Litig., 471 F.3d 24, 30 (2d Cir. 2006) (discussing the "implied requirement of ascertainability"). It is not clear that it is possible to do so.

96. FED. R. CIV. P. 23.

97. In re Cendant Corp. Sec. Litig., 264 F.3d 201, 244 (3d Cir. 2001). 
inconvenient interests. In other words, it is arguable that representative plaintiffs must take their classes as they are found. If much of a class would prefer not to sue, the court must respect their interests as they are found in the real world. ${ }^{98}$

On the other hand, it may be that a class action is literally nothing more than a device that permits the court to deal with many cases at once. The possibility that some buyers may prefer not to sue-or more precisely prefer that others not sue-may be utterly irrelevant. Nevertheless, it is difficult to believe that a court would certify a class action in which the named plaintiff seeks to exclude some subgroup from the class for no substantive reason at all. To be sure, this would be an unusual tactic because a plaintiff lawyer has a strong incentive to make the class (and hence the fee) as large as possible. But the point is that absent class members have an interest in being included unless there is a good reason for being excluded - and particularly so in a securities fraud class action where the settlement will ultimately be paid out of corporate funds and will deplete the wealth of those who are excluded.

Moreover, securities fraud class actions are different from other types of class actions. It may not be worrisome that a potential class member in a products liability action (for example) might be excluded from the class because of some peculiarity about his claim. Such a plaintiff can always bring suit individually. More important, the fact that others are able to join in a class action does no harm to those who are excluded (other than possibly depleting the resources of the defendant). But securities litigation is different because the gain of some class members comes at the expense of other class members who lose more from feedback than they recover. Although the named plaintiff might argue that such potential class members should be excluded from the class simply because they give rise to a conflict within the class, to do so is effectively to increase their losses by denying what minimal recovery they might enjoy.

In the real world, the courts usually try to avoid intra-class conflicts by forming subclasses. But that solution does not work in a securities fraud class action because it raises a multitude of individual questions about who belongs in what class. Technically speaking, these are problems of manageability or the ability to ascertain who is in the class. They are not

98. See Hamilton v. O'Connor Chevrolet, Inc., No. 02 C 1897, 2006 U.S. Dist. LEXIS 44149 , at $* 50$ (N.D. Ill.) (denying class certification in a suit brought by purchasers of an automobile where injuries would differ too greatly among members of the putative class); Hyderi v. Washington Mut. Bank, FA, 235 F.R.D. 390, 403 (N.D. Ill. 2006) (holding that a putative class representative may not define the common issue narrowly and then leave any non-common issues to later proceedings). 
individual questions going to the merits. But they are nonetheless individual issues that preclude certification. ${ }^{99}$

To be clear, the intra-class conflicts that infect class actions arise even in the absence of a possible derivative action. In a world with diversified, portfolio-balancing investors, there will always be a significant number of class members who would prefer that the action simply be dismissed even if it is meritorious. No such inherent conflict infects a derivative action. In a world without securities fraud class actions, no stockholder-other than a guilty insider-would object to the prosecution of a meritorious derivative action. ${ }^{100}$

\section{B. $\quad$ Additional Rule 23(b)(3) Factors}

Standing alone, the problems with adequacy of representation are enough to deny certification. But these are not the only problems that must be addressed. Under Rule 23(b)(3) the court must find that common questions of law or fact predominate over individual questions and that a class action is superior to other methods for fairly and efficiently adjudicating the controversy. ${ }^{101}$

99. See generally In re Initial Pub. Offering Sec. Litig., 471 F.3d at 42 (rejecting arguments that, in a motion for class certification, a court cannot decide on questions of fact which overlap with the merits in considering Rule 23's requirements of predominance and superiority).

100. The analysis here is somewhat complicated by the peculiarities of federal securities law in the context of class actions. Under PSLRA, the court must designate the lead plaintiff and must ordinarily designate the class member with the most at stake (if that class member wants the job). 15 U.S.C. $\S 78 u-4(a)(3)(B)$ (2006). This procedure makes it clear that a class action does not really belong to the plaintiff who files it and further suggests that the plaintiff cannot ultimately decide how the plaintiff class will be defined. Under the PSLRA lead-plaintiff rule, it might be possible, for example, for an index fund to seek to be appointed as the representative plaintiff and then to have the action dismissed or decertified. It is not clear how the courts would react to a representative plaintiff who sought dismissal or decertification. As a matter of procedure, a prospective representative plaintiff must seek the job and must presumably disclose to the court any plan to oppose certification or seek dismissal. That would clearly bear on whether the prospective representative could fairly and adequately represent the interests of the class. Thus, the court would effectively decide whether to certify the class at the same time that it appoints the representative plaintiff. Incidentally, the requirement that the plaintiff with the largest claim be designated as the representative plaintiff supports the idea that the court should manage a class action in the interest of the most numerous population of stockholders, namely, diversified stockholders and indeed portfolio-balancing, diversified stockholders, where such interests come into conflict with those of undiversified investors.

101. FED. R. CIV. P. 23. Rule 23(a) applies to all class actions and requires that the claims of the representative plaintiff be typical of the claims of the class members. Rule 23(b)(3) applies to any class action seeking individual damages on behalf of class members. Thus, the predominance requirement therein is in addition to the typicality requirement. Although most courts that have considered the question have suggested that the two requirements are essentially the same, it is difficult to believe that the predominance 


\section{Predominance of Common Questions}

In order to make out a claim for securities fraud under Rule 10b-5, the plaintiff must prove (1) a material misrepresentation or omission by the defendant, (2) scienter, (3) reliance by the plaintiff on the misrepresentation or omission, (4) economic loss, and (5) loss causation. ${ }^{102}$ With the exception of reliance, these elements need be proven only once in a class action. Before 1988, there was some doubt about the need to prove reliance by each individual class member in cases involving positive misrepresentations (as opposed to omissions). ${ }^{103}$ The Supreme Court resolved this issue in Basic, Inc. v. Levinson by adopting what has come to be known as the fraud-on-the-market theory. ${ }^{104}$ In essence, Basic holds that where a stock is actively traded, a court may presume that the investor relies on the integrity of the market price and thus any misrepresentations that may have affected that price. But the Supreme Court made it quite clear that the presumption is rebuttable:

Any showing that severs the link between the alleged misrepresentation and either the price received (or paid) by the plaintiff, or his decision to trade at a fair market price, will be sufficient to rebut the presumption of reliance. For example, if petitioners could show that the "market makers" were privy to the truth about the merger discussions here with Combustion, and thus that the market price would not have been affected by their misrepresentations, the causal connection could be broken: the basis for finding that the fraud had been transmitted through market price would be gone. Similarly, if, despite petitioners' allegedly fraudulent attempt to manipulate market price, news of

requirement is nothing more than a redundancy. The presumption must be that it creates an additional somewhat higher hurdle in actions for damages. See Dukes v. Wal-Mart Stores, Inc., 603 F.3d 571, 590-94 (9th Cir. 2010) (en banc), rev'd by Wal-Mart Stores, Inc., v. Dukes, 131 S. Ct. 2541, 2559-60 (2011) (applying a separate predominance test as a hurdle for a plaintiff seeking class certification to meet).

102. Dura Pharm., Inc. v. Broudo, 544 U.S. 336, 341-42 (2005).

103. As the Supreme Court stated in Basic, Inc. v. Levinson, 485 U.S. 224, 242 (1988):

Requiring proof of individualized reliance from each member of the proposed plaintiff class effectively would have prevented respondents from proceeding with a class action, since individual issues then would have overwhelmed the common ones. The District Court found that the presumption of reliance created by the fraud-on-the-market theory provided 'a practical resolution to the problem of balancing the substantive requirement of proof of reliance in securities cases against the procedural requisites of [Federal Rule of Civil Procedure] 23.' The District Court thus concluded that with reference to each public statement and its impact on the open market for Basic shares, common questions predominated over individual questions, as required by Federal Rules of Civil Procedure 23(a)(2) and (b)(3).

104. Id. 
the merger discussions credibly entered the market and dissipated the effects of the misstatements, those who traded Basic shares after the corrective statements would have no direct or indirect connection with the fraud. Petitioners also could rebut the presumption of reliance as to plaintiffs who would have divested themselves of their Basic shares without relying on the integrity of the market. For example, a plaintiff who believed that Basic's statements were false and that Basic was indeed engaged in merger discussions, and who consequently believed that Basic stock was artificially underpriced, but sold his shares nevertheless because of other unrelated concerns, e.g., potential antitrust problems, or political pressures to divest from shares of certain businesses, could not be said to have relied on the integrity of a price he knew had been manipulated." 105

It is fair to presume that a well-diversified, portfolio-balancing investor relies on the integrity of market prices when she trades. Such an investor is (almost) by definition a passive price-taker. Indeed, the very idea of portfolio balancing depends on using market prices of portfolio stocks to determine the amount of each stock that one should buy or sell. But it is not at all clear that the same presumption should apply to an undiversified investor. To the contrary, an undiversified investor is by definition a stock-picker who presumably must have some reason for picking the stocks he picks. In other words, such an investor may be presumed to choose a stock precisely because he thinks the market price is wrong in some sense. To be sure, such an investor must think the price is too low when instead it is too high. Nevertheless, it is fair to presume that an undiversified investor bases his investment decisions on something other than the integrity of the market price.

Basic is an unusual case and less than an ideal precedent. It is atypical in that it involves a cover-up of good news, whereas the vast majority of securities fraud class actions involve the cover-up of bad news. ${ }^{106}$ As a

105. Id. at $248-49$.

106. As noted above, data for one recent year show that only 2 out of 119 securities fraud class actions involved the cover-up of good news. One might think that this skewing is the result of a natural tendency to delay the disclosure of bad news in the hope that it might go away or (more cynically) because bad news is a better opportunity for insider trading because one can be more certain that bad news will cause stock price to decline than one can be certain that good news will cause stock price to increase. But feedback is probably a more important reason for the predominance of bad-news cases. To be specific, securities fraud class actions have the effect of magnifying the effects of bad news but of muting the effects of good news (which may also limit the opportunities for insider trading in good-news cases). In any event, one would expect a somewhat more even distribution between good-news cases and bad-news cases. The fact that the numbers are as skewed as they are suggests that there must be some distorting factor at work. That factor is securities fraud class actions. 
result, the court illustrates its point by suggesting that there may be cases in which an investor sells a stock even though he thinks it may be underpriced. The problem is that one would never buy a stock that one thinks is overpriced. The fact that the plaintiffs in Basic already held Basic shares is crucial to the analysis. What the court probably should have said is that it makes no difference why one sells (or buys). The whole idea of reliance on the integrity of the market - rather than reliance on market price - is that one can presume that the market price is fair and nonetheless decide to trade.

Nevertheless, it is possible to imagine a situation involving a buyer that is roughly parallel to the examples given by the Court in Basic. For example, suppose that a company has announced that it expects sales to increase over the next year, but the investor thinks that sales will be weak. Moreover, the investor thinks that the market also thinks that sales will be weak and has discounted share price. But the investor thinks the market has overreacted. So the investor buys the stock. It seems clear that the presumption of reliance would be rebutted in such a situation.

To be fair, it is conceivable that an investor might pick a stock that he thinks is likely to increase in price (by more than the market as a whole) while at the same time he thinks the stock is fairly priced - or at least not fraudulently priced. Indeed, that would seem to be a more or less normal way for an investor to think even if it is ultimately misguided to do so. And it is probably the reason that the court used the phrase "integrity of the market price" rather than a more straightforward formulation suggesting that the market price is presumed to be correct. ${ }^{107}$ In other words, there is no inherent contradiction between stock-picking and reliance on market price. $^{108}$

It is also conceivable that some undiversified investors choose individual stocks that they think are safe investments for the long haul and do in fact rely on the integrity of the market price in doing so. But such an investor is much more likely to invest in a diversified portfolio of stocks as a way of reducing risk even more (and at little or no cost) and indeed as a way of hedging against the possibility that the stock is overvalued. So even if there are some such safety-seeking investors who remain undiversified, it seems likely that many undiversified investors choose stocks because they think the market price is wrong.

The bottom line is that, even if there are some undiversified investors

107. Basic, Inc., 485 U.S. at 247.

108. The idea of the integrity of the market price also makes it clear that market prices may change for reasons that do not give rise to a claim for securities fraud. In other words, the idea is that the process by which prices are set is fair even if the price itself is not always fair. So the idea of the integrity of the market price leaves plenty of room for the courts to distinguish between cases in which investors have a remedy and those in which they do not. 
who do rely on the integrity of the market price, there is no reason to presume that they do so. Indeed, it is fair to presume that a significant number of undiversified investors trade because they think the market price is wrong. That alone is enough to raise significant individual questions that preclude class certification.

Even if it could be presumed that all of the buyers in the potential plaintiff class relied on the market price (or the integrity thereof), important individual questions remain to be resolved in determining who should be in the plaintiff class. Assuming for the sake of argument that the court has ruled that a class action may proceed in which the plaintiff class will comprise only those buyers who stand to gain more than they lose if the action succeeds, how would the representative plaintiff go about identifying the members of the class? As discussed above (and still further in the appendix), the determination of who should be in the class would depend on the number of shares bought versus the number of shares held and the ultimate size of the plaintiff class. So there is no way to determine the size of the plaintiff class unless the size of the plaintiff class is already known. To be sure, one could in theory determine the holdings and purchases of every stockholder of the subject company at every moment during the class period. But that would involve discovery from a large number of investors who will ultimately be excluded from the plaintiff class.

Another possibility is that the plaintiff would limit the class to investors who bought the subject stock during the fraud period but who did not hold any shares of the subject stock that were acquired before the fraud period began. Adequacy of representation notwithstanding, this seems like a relatively simple definition, but it is not clear how each investor would prove that she did not own some shares from before the class period. There would be significant incentive (and opportunity) to cheat since buyerholders would want to recover what they could if the class action proceeds. $^{109}$

Admittedly, these individual issues are not about the merits of the corresponding claims. Rather, they are issues that relate more to the definition of the class. Thus, one might argue that they are not really issues of preponderance but rather issues of manageability. Nevertheless, the issues are real and the courts have considered them under the rubric of

109. Moreover, a class as so defined may be so small that it might not even satisfy the numerosity requirement under Rule 23(a). Nevertheless, given that the ultimate size of the plaintiff class as so defined is likely to be quite small, feedback is likely to be minimal. Thus, it might be argued that feedback loss can safely be ignored. But if one ignores feedback loss, the plaintiff class swells to include anyone who bought any shares during the fraud period, including those who owned significant numbers of shares acquired earlier, and feedback once again becomes a factor. 
preponderance. ${ }^{110}$ And even if they are not really issues of preponderance, manageability is itself a factor to be considered, as discussed further below.

\section{Superiority}

In addition to requiring that common questions predominate, an action may be certified as a Rule 23(b)(3) class action only if the Rule 23(b)(3) class action is superior to other modes of litigation, including the other categories of class actions set forth in the rule. Moreover, in determining whether a class action is superior, Rule 23(b)(3) requires the court to consider: (A) the interests of members of the class in individually controlling the prosecution or defense of separate actions, (B) the extent and nature of any litigation concerning the controversy already commenced by or against members of the class, (C) the desirability or undesirability of concentrating the litigation of the claims in the particular forum, and (D) the difficulties likely to be encountered in the management of a class action. All of these factors are problematic. Factor (A) is a problem because many members of the class would prefer that derivative claims be prosecuted derivatively and that direct claims be dismissed. Factor (B) is a problem because a derivative action arguably provides complete relief without untoward side effects. Factor $(\mathrm{C})$ is a problem because a derivative action is better handled in state court. Finally, factor (D) is a problem, because (among other things) (1) it is difficult to draw the line between diversified and undiversified investors, and (2) undiversified investors must presumably show reliance.

\section{a. Member Interest}

The first superiority factor that must be considered is the interest of members of the class in individually controlling the prosecution or defense of separate actions. It seems clear that if there are claims that can be addressed either as direct claims or as derivative claims, they should be addressed as derivative claims. This is not to say that a claim can be both direct and derivative (although that may be possible). Rather, as shown here, there are elements of potential recovery that should be handled as derivative claims even though they are usually treated as part of the class claim. It may suffice simply to show that such claims are derivative since

110. See, e.g., In re Initial Pub. Offering Sec. Litig., 471 F.3d 24, 29-31 (2d Cir. 2006) (describing a preponderance standard for courts to apply in determining whether a plaintiff has meet the requirements of Rule 23); Dukes v. Wal-Mart Stores, Inc., 603 F.3d 571, 594 (9th Cir. 2010) (en banc), rev'd by Wal-Mart Stores, Inc., v. Dukes, 131 S. Ct. 2541, 255152 (2011) (holding that district courts may also consider issues overlapping with the merits in completing a Rule 23 analysis). 
it is not clear that a court has discretion to treat such claims as direct. It is also arguable that the derivative action is the default rule. In other words, the burden is on the party that would maintain a class action to show why it should not be maintained as a derivative action. ${ }^{111}$ But the point is that some members of the plaintiff class have a compelling interest in seeing the claims litigated as derivative claims.

Although this factor focuses on the interests of members of the class, one obviously needs to know who is in the class in order to consider their interests. Thus, this factor depends on the definition of the class. If the action is pursued derivatively, one could argue that all of the stockholders (including mere holders and perhaps the corporation itself) are in fact members of the class. ${ }^{12}$

111. See infra note 113 and accompanying text.

112. In a setting other than securities litigation, if a large number of class members choose to opt out of the class action, either at the outset or by failure to file a claim, it is presumably a good indication that the class action is not superior to other ways of resolving the dispute. There is no need for the court to look into why so many potential class members opted out - the fact speaks for itself. Accordingly, the courts have declined to certify such actions or have decertified such actions as were previously certified. But securities litigation is different. Many buyers will rationally decline to opt out even though they oppose securities fraud class actions because by opting out they lose even more.

One possible way to circumvent such strategic behavior might be to poll the potential class to determine if a class action should proceed as a class action or as a derivative action. Such a vote of the potential plaintiff class would be a better way to get an accurate reading of investor preferences than the opt-out system. With a vote, potential class members could register their preferences without the need to sacrifice class membership if the action goes forward. That is, a diversified investor could vote NO in the hope that the action will be dismissed. If the action goes forward, he may remain in the class and get his share of any recovery. In short, voting would be much more sensible than the opt-out system we have.

For a discussion of similar advantages in connection with stockholder voting as compared with tender offers as a way of assessing stockholder preferences, see Richard A. Booth, The Promise of State Takeover Statutes, 86 Mich. L. REV. 1635 (1988) and Richard A. Booth, The New Law of Freeze-Out Mergers, 49 Mo. L. Rev. 517 (1984). Such a vote may be authorized implicitly under the notice provisions of Rule 23(c). One potential problem with voting is that only buyers may be class members in an action for damages, and a court might well limit the vote to potential class members. Moreover, a diversified investor who is opposed in principle to securities fraud class actions may nonetheless vote for an individual class action because he gets to vote only when he might gain from the action.

Indeed, a diversified investor may figure that he really must vote in favor of the class action (painful as it is to do so) because other diversified investors (who may not understand their interests so well) will vote in favor of other actions in which they stand to gain. So even if the matter is put up to a vote, an investor may vote in favor of a class action - even though he opposes class actions in principle - because he must remain in the actions for which he is eligible in order to recoup the losses he suffers from actions in which he is a mere holder.

The one group that will invariably vote against a class action is non-buyer holders. But it is not clear that they can vote unless the vote is one of all potential class members 


\section{b. Other Litigation}

The second superiority factor that must be considered is the extent and nature of any litigation concerning the controversy already commenced by or against members of the class.

It seems clear that if a derivative action is pending, a court may decline to certify the class action as a class action on grounds that the derivative action is superior (even though it covers only a portion of the class claim). But what if no derivative action has been filed? Can the court convert a class action into a derivative action? And can a court do so on its own motion? The question is somewhat academic in that there is nothing to stop a diversified investor from filing a derivative action when warranted. But even in the absence of a pending derivative claim, it seems quite clear that a court may convert a direct action into a derivative action on its own motion.

First (and again), the characterization of an action is a matter for the court. It is not up to the representative plaintiff to decide what form the action will take. ${ }^{113}$ The characterization of the action is akin to a question of subject matter jurisdiction that the court can raise on its own motion. Indeed, it is difficult to see how the law could be otherwise in the context of a representative action involving absent parties. And this is particularly true in the context of securities litigation where PSLRA and SLUSA have given the courts even more power to manage class actions. Not only does the court have the power to appoint a representative plaintiff, it also has the power to treat multiple individual actions as class actions even when they are not filed as such. The court can also remove state actions that assert direct claims based on a failure of disclosure even where the result is to dismiss the claim as a matter of federal law. ${ }^{114}$ Moreover, SLUSA

including those who might be class members (so to speak) in a derivative action. (One way that the vote could be conducted would be to permit all stockholders to vote either for a class action or a derivative action.) Finally, as a practical matter, few individual investors would bother to vote or vote intelligently if any such vote were conducted. This too may justify judicial intervention.

On the other hand, institutional investors - who presumably have the most votesmight consider the matter quite seriously. Even in the absence of a vote, the fact that many investors might be inclined to vote strategically and contrary to their overall interest suggests that securities fraud class actions are infected by a market failure that justifies a court-particularly in a representative action - to consider the interests of absent class members in deciding whether to certify a securities fraud action as a class action. This is discussed further in connection with policy considerations in Section IV. infra.

113. See, e.g., Smith v. Waste Mgmt., Inc., 407 F.3d 381, 382 (5th Cir. 2005); Cowin v. Bresler, 741 F.2d 410, 414 (D.C. Cir. 1984); Shirvanian v. DeFrates, 161 S.W.3d 102, 110 (Tex. App. 2004) (providing examples of courts deciding that the claims at issue had to be brought as a derivative ones).

114. Securities Exchange Act of $1934 \S 21 D, 28(f), 15$ U.S.C. $\S \S 78 u-4,78 b b(f)$ (2006). 
expressly exempts state law derivative claims from federal preemption even in cases in which the claim is based on a failure of disclosure. Clearly, this regulatory scheme depends on the courts to distinguish direct actions from derivative actions and indeed to recharacterize one as the other when necessary.

Second, Rule 23 itself seems to contemplate both types of actions. To be sure, Rule 23.1 expressly addresses derivative actions. But Rule 23(b)(2) also speaks to the issue in that it states that a class action may be maintained if "the party opposing the class has acted or refused to act on grounds generally applicable to the class, thereby making appropriate final injunctive relief or corresponding declaratory relief with respect to the class as a whole." 115 Thus, Rule 23 apparently overlaps with Rule 23.1. Indeed, it is often said that a derivative action is really two actions in one: an equitable action to compel the corporation to sue and an action by the corporation seeking damages or restitution from those who did the corporation wrong.

The question is: Can (or should) the court certify an action under Rule 23(b)(3) when it could also certify an action under Rule 23(b)(2)? The rules quite clearly answer this question in the negative. Rule 23(b)(3) is available only if the action cannot be certified under another category. ${ }^{116}$ Moreover, a derivative action represents a greater number of stockholders in that it represents buyers, buyer-holders, and holders. To be sure, mere holders have no standing to sue for damages under federal law and thus may not be class members in an action for damages. But a holder may maintain a derivative action. Indeed only a holder may maintain a derivative action. ${ }^{117}$ Admittedly, per share recovery is likely to be smaller in a derivative action because the recovery is spread over a larger number of stockholders. And the aggregate amount at issue is likely to be smaller since it does not include the fundamental decrease or feedback. But buyers effectively recoup some of the losses they would have suffered because there is no feedback effect in a derivative action as there is in a class action. ${ }^{118}$ Buyers can hardly complain about a smaller recovery if it is

See, e.g., Merrill Lynch, Pierce, Fenner \& Smith Inc. v. Dabit, 547 U.S. 71, 74 (2006) (holding that SLUSA applies broadly to preempt state-law class action claims brought by holders of securities).

115. FED. R. CIV. P. 23(b)(2).

116. See DeBoer v. Mellon Mortg. Co., 64 F.3d 1171, 1175 (8th Cir. 1995) (finding that certification is appropriate under subsection (b)(2) if classwide injunctive relief is sought when the defendant "has acted or refused to act on grounds generally applicable to the class").

117. See FED. R. Civ. P. 23.1 (requiring that the representative plaintiff in a derivative action must have been a stockholder in the company at the time of the wrong).

118. Again, if the plaintiff class comprises $50 \%$ of the stockholders, feedback will double the price decrease. So if such an action is styled as a derivative action rather than a 
because they suffered a smaller loss in the first place.

Finally, and perhaps most important, a successful derivative action leaves a buyer in exactly the same position that she would have been in if there had been no fraud. If there had been no fraud, the buyer presumably would have bought and suffered a loss when stock price fell.

\section{c. Forum Choice}

The third superiority factor that must be considered is the desirability or undesirability of concentrating the litigation of the claims in the particular forum. Arguably, this factor has been rendered largely irrelevant by the possibility of multidistrict litigation. But it takes on new relevance if some part of the class claim is in fact a derivative claim. Presumably, a state law fiduciary duty claim is more appropriately litigated in state court than in federal court. This is particularly true where the question is one of corporation law. Indeed, the Delaware Court of Chancery-which is the court where most such actions would be litigated - is uniquely well-suited to such litigation. ${ }^{119}$ While it may seem a bit odd to suggest that a federal court should defer to a state court, it is well settled that federal securities law does not supplant the state law of fiduciary duty. Indeed, as discussed above, federal securities law depends largely on the state law of fiduciary duty. ${ }^{120}$ To be sure, there is no reason that a federal court could not hear a case sounding in state law fiduciary duty as long as the federal court has jurisdiction over the matter. But it is also clear that a federal court could refuse to certify a class action because another forum is superior. ${ }^{121}$

\section{d. Manageability}

The fourth superiority factor that must be considered is any difficulty likely to be encountered in the management of the class action. Needless to say, it is much more efficient to treat a claim as derivative rather than direct when it is possible to do so. In a derivative action, the award goes to one claimant-the corporation. There is no need to deal with hundreds or thousands of individual investors or the issues that go with notice and the right to opt out, proof of claims, calculation and payment of awards, and so forth. In short, a derivative action is much simpler to manage.

Moreover, as noted above, there is no good way to know the size of

class action, buyers effectively recover half of their losses from the elimination of feedback.

119. See Booth, supra note 77, at 204-05. And see note 48 supra.

120. See supra note 72 and accompanying text.

121. Presumably, the federal court could retain jurisdiction to resolve any remaining direct claims under federal securities law after the resolution of the state law fiduciary duty claims. 
the plaintiff class in a class action. At first blush, one might think that the number of shares represented in the plaintiff class is equal to the number of shares traded during the fraud period. But it is likely that many of those shares have traded multiple times during the class period. For example, suppose that the class period is one year and that during that time volume for the stock in question-turnover-has been equal to $100 \%$ of outstanding shares. It is possible, though unlikely, that the company now has a completely new set of shareholders. It is also possible that $20 \%$ of the shares traded five times during the year and that $80 \%$ of the shares did not trade at all. There are innumerable possibilities. There is no way to determine the size of the plaintiff class short of sending out notice to everyone who bought during the fraud period. ${ }^{122}$ Although the courts have managed to deal with this problem in practice, the problem can be eliminated altogether to the extent that claims are resolved in a derivative action in which the corporation recovers for the benefit of all of the stockholders.

Finally, as also noted above, if one considers the differing interests of investors with differing trading styles, it is difficult if not impossible to define the class and to determine who should be a member. Again, the size of the class determines who is likely to favor the class action. But the size of the class cannot be known unless one knows who is likely to favor the class action.

\section{Litigation Strategy}

It may seem curious that no one has raised the argument that some of the typical class claim is really derivative rather than direct. There are

122. In other words, one of the intractable problems with securities fraud class actions is that there is no way to know how many different shares have been damaged because many of the same shares may have been bought and sold during the class period. As in a game of musical chairs, many players may change position, even though only one comes up short. See generally Robert A. Alessi, The Emerging Judicial Hostility to the Typical Damages Model Employed by Plaintiffs in Securities Class Action Lawsuits, 56 Bus. LAw. 483 (2001). Thus, under current practice the courts do not usually know how many shares are represented by the plaintiff class or the aggregate amount of damages that would be awarded if the plaintiff wins. Needless to say, ignorance of the potential damages makes settlement negotiations difficult. It has also led to the invention of some highly questionable models that purport to estimate the number of damaged shares. Id. at 488-89. Alessi argues that notice should go out and that class members should be required to file claims (together with documentation) before the court approves any settlement because that is the only way to determine accurately the number of damaged shares. It seems odd that such is not the usual practice anyway. One would think that a class member should be required to declare before knowing the outcome. But that might necessitate the expense of notice on two occasionsonce to solicit claim forms and (possibly) a second time to approve the settlement. Indeed it has become a common practice in class actions outside securities fraud class actions to send multiple rounds of notice. See FED. R. CIV. P. 23(d)(1)(B). 
several answers.

First, it may be that plaintiffs worry that insurance may not cover many derivative claims. Since a derivative claim is one by the corporation usually against its own directors and officers, it may not be clear that insurance will pay. ${ }^{123}$ The same reasons may also explain why corporations do not seek to recharacterize class actions as derivative actions in order to take control and either dismiss or settle the claim. Management-the potential individual defendants - may worry that they would not be covered by insurance in connection with a derivative claim. ${ }^{124}$

Second, since in a derivative action the corporation is the real plaintiff and management is the primary defendant, it is impossible for the two to present a unified defense. In a class action, the corporation and management can circle the wagons and fight the plaintiffs together. ${ }^{125}$

123. This may also explain why the plaintiff lawyers who do handle derivative actions have declined to challenge those who handle class actions. It may be that class action lawyers are willing (in effect) to share their fees with derivative action lawyers and that for the latter the practice is lucrative enough to forgo asserting the primacy of the derivative action.

124. Litigation is often mostly about settlement. Although the merits matter-at least in the sense that the law must provide for a claim if one is to have a case-litigation is often an extension of negotiation. It may be that it is easier for a corporation to persuade its insurance company to pay others than to pay the corporation that bought the policy. Indeed, it appears that most insurance companies permit the defendant corporation to direct the defense of securities fraud class actions. An insurance company may not be so accommodating in a derivative action where management is effectively on both sides of the litigation. Moreover, it is not at all clear that directors and officers insurance as currently written would cover all of the derivative claims discussed here. On the other hand, there is no reason why an insurance company should not be interested in offering a new product if there is money to be made. For example, AIG offered earnings insurance for a time. That is, it offered a policy that would make up for a covered earnings shortfall. See Richard A. Booth, Reducing Risk Doesn't Pay Off, Wall St. J., Mar. 15, 1999, at A18 (arguing that stock holders, on average, do not like risk management instruments). Moreover, it has been suggested that one way to assure that auditors do not kowtow to the companies they audit might be for them to buy insurance against earnings restatements, which would induce the insurance companies to monitor both reporting companies and their auditors. An insurance company would likely pay out less in a derivative action than in a class action. On the other hand - in the grander scheme-insurance companies may make more money by selling policies to cover larger claims. Nevertheless, saving now by paying out less is a bird-inhand. Here market failure may militate for the right result. Finally, it might also be possible to devise a governance provision akin to Delaware's $\S 102(\mathrm{~b})(7)$ that deals with the redistribution problem by limiting the right of any stockholder to seek compensation from the company or providing that in the event a securities fraud class action is filed against the company, the company may assume control of the action as in a derivative action. DEL. CODE ANN. tit. 8, § 102(b)(7) (2012).

125. See Pfeiffer v. Toll, 989 A.2d 683 (Del. Ch. 2010), abrogated by Kahn v. Kolberg Kravis Roberts \& Co., 23 A.3d 831, 836-40 (Del. 2011). On the other hand, if management prevails, it presumably will be indemnified by the corporation. Indeed, even if management is held liable to the corporation, it may be indemnified by court order as long as no personal benefit was involved. 
Third, the procedures governing derivative actions are not plaintifffriendly. The representative plaintiff must make a demand on the board of directors to sue-since the claim belongs to the corporation-unless it would be futile to do so. And even in cases of demand futility, the corporation can later take control of derivative action and seek to have it dismissed as contrary to the best interests of the corporation. ${ }^{126}$ So the plaintiff lawyer has much less control over a derivative action than a class action. Indeed, there is a perception that corporations are able to have derivative actions dismissed in many meritorious cases. On the other hand, there is little doubt that corporations settle many securities fraud class actions that are not meritorious.

Fourth, even though the courts have the power (if not the duty) to recharacterize a portion of the typical class action claim as derivative, it also seems unlikely that the courts will do so on their own motion. Moreover, individual courts cannot escape their own opt-out problem: Other courts may continue to certify class actions to the detriment of the diversified investors. No court other than the Supreme Court can afford to give too much thought to cases other than the one before it.

Finally, it may be that no one ever thought to make the argument (if I do say so myself). ${ }^{127}$ The most likely party to advocate for any such change would seem to be an index fund, since as a portfolio-balancing investor, such a fund almost always loses more from securities fraud class actions than it gains. The problem is that not even index funds really appreciate the fact that they lose more from securities fraud class actions than they gain. It is difficult to appreciate the costs when the only tangible evidence one ever sees is a big settlement check. ${ }^{128}$

\section{POLICY CONSIDERATIONS}

To be clear, it is not the argument here that the courts should deny certification because investors in the aggregate would be better off in a world without securities fraud class actions (even though that is true). Rather, the argument is (1) that part of the claim in any meritorious securities fraud class action is in fact derivative rather than direct, (2) that intra-class conflicts preclude certification, (3) that individual questions as to reliance and the definition of the class overwhelm common questions,

126. See, e.g., Joy v. North, 692 F.2d 880, 887 (2d Cir. 1982) (stating that, "in the normal course of events, a decision whether to bring suit is a corporate economic decision subject to the business judgment rule.").

127. But see In re Cendant Corp. Sec. Litig., 109 F. Supp. $2 d 235$ (D.N.J. 2000); In re Cendant Corp. Sec. Litig., 109 F. Supp. 2d 285 (D.N.J. 2000); aff'd, 264 F.3d 201 (3d Cir. 2001).

128. See Richard A. Booth, Index Funds and Securities Litigation (forthcoming). 
and (4) that a derivative action is superior to a class action.

Although the foregoing arguments against certification are convincing (if not overwhelming), the fact remains that the remaining direct claims of individual buyers for investment losses (if any) cannot be litigated by derivative action unless one allows for individual recovery against individual defendants. This does not necessarily mean that buyers have lost their remedy. It is always possible for a buyer to sue individually or together with other buyers (as long as the number of plaintiffs is fewer than fifty). ${ }^{129}$ All that is lost is the ability to maintain a class action (which is hardly a matter of right). Indeed, in many ways it may be preferable not to proceed by class action since one can avoid the additional hurdles imposed on class actions by PSLRA and SLUSA. ${ }^{130}$

Still, to be realistic, it is unlikely that many individual investors will sue in the absence of the ability to maintain a class action. The practical implication is that individual claims for investment losses will simply go uncompensated - a wrong (perhaps) without a remedy. So, the question is, should the courts muscle through the requirements of Rule 23 in order to maintain the institution of securities fraud class actions however flawed they may be? Is the fact that securities fraud will go unavenged a good enough reason to permit class actions to go forward?

One obvious argument for keeping securities fraud class actions is that they provide an important source of deterrence. In their absence, managers might be inclined to cover up bad news and even to lie to the market. The obvious response is that a derivative action also provides deterrence. Moreover, most observers agree that as a disciplinary tool, securities fraud class actions are overkill. ${ }^{131}$ A derivative action is a more proportional response. So deterrence is no rationale for a class action.

129. Under SLUSA, all actions for individual damages based on a theory of nondisclosure and involving fifty or more plaintiffs must be handled as federal class actions. Securities Exchange Act of 1934 § 28(f), 15 U.S.C. § 78bb(f) (2006).

130. One of the big attractions of class actions is that attorney fees get paid out of the award. See FED. R. CIV. P.23(h). But the same is effectively true in a derivative action where attorney fees are paid by the corporation on the theory that the derivative action benefits all of the stockholders and not just those who filed suit. A.L.I., PRINCIPLES OF CORP. GOVERNANCE $§ 7.17$ (1994).

131. See John C. Coffee, Jr., Reforming the Securities Class Action: An Essay on Deterrence and its Implementation, 106 Colum. L. REV. 1534, 1585 (2006) (arguing that securities litigation is "a process by which the parties shift liabilities created by the corporate managers onto shareholders through the medium of costly insurance paid for by shareholders."); Amanda M. Rose, Reforming Securities Litigation Reform: Restructuring the Relationship Between Public and Private Enforcement of Rule 10b-5, 108 CoLuM. L. REV. 1301, 1363 (2008) (arguing that "[c]lassic law and economics scholarship, however, casts considerable doubt on the desirability of utilizing Rule 10b-5 class actions as an additional deterrent."); see also COMMITTEE ON CAPITAL MARKETS REGULATION, INTERIM REPORT OF THE COMMITTEE ON CAPITAL MARKETS Regulation 78-79 (2006) (evaluating "the legal and regulatory underpinnings of U.S. public capital markets"). 
Neither do investors have any need for a direct remedy. It is not clear that investors suffer any genuine harm beyond the harm that can be remedied by a derivative action. Again, diversified investors are hedged against securities fraud by virtue of being diversified. They are just as likely to sell an overpriced stock as they are to buy one. It all comes out in the wash. Indeed, the cost of litigation is a deadweight loss to the system that ultimately reduces investor return. Clearly, diversified investors would be better off in a world without securities fraud class actions. ${ }^{132}$ To be sure, securities fraud class actions may make sense from the viewpoint of an undiversified investor. An undiversified investor may suffer real harm from securities fraud. An investor who forgoes the benefits of diversification and picks a few good stocks runs the risk that one of those stocks will be the next Enron or WorldCom. ${ }^{133}$ On the other hand, such an investor may gain if she happens to sell an overpriced stock. Moreover, such an investor may also lose as a mere holder. Thus, even an undiversified investor would oppose securities fraud class actions if she were utterly risk-neutral. Nevertheless, for an undiversified investor, the benefits of securities fraud class actions may outweigh the costs. ${ }^{134}$

132. To the contrary, Alicia Davis has argued that many investors may lose from securities fraud - and that many investors may also win - but that diversification does not guarantee that losers will balance out winners for all investors. Alicia J. Davis, Are Investors' Gains and Losses from Securities Fraud Equal Over Time? Theory and Evidence (Empirical Legal Studies Ctr. at Univ. of Mich. Law Sch., Working Paper No. 09-002, 2010). Indeed, she argues that most investors will either be net losers or net winners and that relatively few will break even. In addition, using Monte Carlo simulations involving investors who use a variety of trading strategies, she shows that on average and in the aggregate investors lose a little more from securities fraud than they gain. While the former goes without saying, Davis offers no good explanation for the latter, other than to suggest that to gain from securities fraud one must own a fraud-affected stock and then sell it before the truth comes out (which she suggests is less likely than simply buying a fraud-affected stock). Although it is a mystery why investors should on average come out just a little behind as a result of securities fraud, that does not show that investors would therefore favor a class action remedy. First, the study apparently assumes all or nothing trading, which is not likely to be the pattern of most investors. Second, the study does not account for the losses that holders suffer as a result of securities fraud class actions. And needless to say, the study does not factor in any recovery that investors might enjoy as a result of meaningful derivative recovery.

133. Studies indicate that the average individual investor holds four different stocks. See supra note 16 and accompanying text. If one of those stocks turns out to be worthless, the investor would suffer a twenty-five percent loss (assuming equal weighting by value).

134. It is worth noting here that many courts have permitted actions against trustees for losses on imprudent investments even though the losses are more than offset by gains from other investments and even though trust law requires diversification. See RESTATEMENT (SECOND) OF TRUSTS § 213 (1959); see generally Jeffrey N. Gordon, The Puzzling Persistence of the Constrained Prudent Investor Rule, 62 N.Y.U. L. REV. 52 (1987) (criticizing the so-called anti-netting rule). This suggests that many courts may not appreciate the significance of diversification, which in turn may explain why the courts have tolerated securities fraud class actions. 
It may be helpful to think about securities fraud class actions as a form of investment insurance. People usually buy insurance against major losses. They do not usually buy insurance against minor losses. A diversified investor is naturally insured against securities fraud by virtue of being diversified. She cannot lose much even if one of her stocks proves to be worthless. For a diversified investor, it is a waste of money to buy additional insurance because one is already covered. One is self-insured. But an undiversified investor may find insurance to be worth the cost. Just as one may gain peace of mind from buying insurance - even though one pays but never collects - an undiversified investor may find it a good deal to be protected against securities fraud by securities fraud class actions. In other words, insurance always costs a bit more than it is worth - otherwise, insurance companies would go out of business. But it may still be worth the candle to buy insurance. For an undiversified investor, securities fraud class actions are similar to buying fire insurance on one's house, whereas for a diversified investor, securities fraud class actions are equivalent to buying an extended warranty on a toaster. ${ }^{135}$

135. There is an important difference between insurance and diversification, however. By definition, insurance costs more than it is worth because in the aggregate the insurance company pays out less in benefits than it charges in premiums. Nevertheless, insurance may still be a good deal for the buyer if the risk avoided is particularly worrisome. (This also explains why options, futures, and other derivatives have value for investors even though the transaction is zero-sum.) In other words, the individual buyer of insurance may gain even though buyers lose in the aggregate. As with diversification, the value of insurance inheres in spreading the risk. Each buyer of insurance agrees in effect to suffer a small fraction of the worrisome loss and to pay a little bit more in addition to the insurance company for its services in spreading the risk. But diversification is a much better deal. First, it is effectively free. Although it may cost a bit in management fees to invest with a mutual fund, it costs as much or more to maintain an individual brokerage account. Second, the risk of loss is eliminated altogether because for every stock that suffers an unexpected loss, there is another that enjoys an unexpected gain. In contrast, there is no upside with insurance. Some number of people will die. Some number of fires will happen. There is no gain (except for the insurance company) if losses fail to materialize. The same is true with fixed-income securities such as bonds and preferred stock. Although one can avoid the danger of catastrophic losses through diversification, such securities do not offer much (if any) upside potential. So there are never any gains to offset loses. One can only minimize losses. Thus, the beauty of diversification in the stock market is due partly to the fact that common stock represents a residual ownership interest in the company. Any unexpected gain goes in effect to the stockholders. The same rationale ultimately justifies the business judgment rule. See generally Richard A. Booth, Stockholders, Stakeholders, and Bagholders (Or How Investor Diversification Affects Fiduciary Duty), 53 Bus. Law. 429 (1998) (discussing the interplay of diversification and fiduciary duties). In most cases, we let losses lie where they fall because investors are presumed to understand that unexpected losses are offset by unexpected gains (at least in the absence of self-dealing or similar duty of loyalty problems). There is nothing to be gained from litigation. The same is true of securities fraud (broadly defined). There is nothing to be gained from litigation since one is just as likely to sell an overpriced stock as to buy one. Indeed, even with securities fraud we let losses lie where they fall unless the plaintiff can show that there was a duty to disclose and 
In the end, there is a fundamental conflict between the interests of diversified investors and the interests of undiversified investors. Diversified investors should be opposed to securities fraud class actions while undiversified investors would likely favor such actions. While undiversified investors may be happy to forgo some investment return for the peace of mind that goes with being (somewhat) insured against catastrophic losses, diversified investors do not want or need such protection. Nevertheless, they are forced to pay for it for the benefit of undiversified investors. ${ }^{136}$

Since there is no way that the law can serve both diversified and undiversified investors at the same time, the ultimate question is which class of investors to favor. The answer is really quite easy. In case of conflict, the law should favor diversified investors. First, it is clear that diversified investors constitute the larger population of investors. ${ }^{137}$ Second, investors should be presumed to be diversified. It is irrational for passive investors - most investors - not to diversify because by doing so one can eliminate the company-specific risk that goes with picking stocks and investing in individual companies without any reduction in expected return. The ultimate goal for an investor is to maximize return at a given level of risk. It is therefore irrational for an investor to fail to reduce risk if it is costless to do so. Federal securities law is intended to protect reasonable investors. ${ }^{138}$ Since reasonable investors diversify, it follows that the interests of diversified investors should trump those of undiversified investors. If there is a need to choose, the choice is clear. The law should presume that a reasonable investor is a diversified investor. ${ }^{139}$

an intentional breach of that duty-scienter.

136. Thus, a securities fraud class action can fairly be characterized as a subsidy running from diversified investors to undiversified investors. Needless to say, if undiversified investors could buy insurance from some other source, diversified investors would presumably have no objection if they did so. Indeed, it is perfectly possible to buy such insurance in the form of options and other derivative instruments. So the fact that diversified investors are effectively required to pay through a system of securities fraud class actions is particularly irksome.

137. See supra note 16 and accompanying text.

138. See TSC Indus., Inc. v. Northway, Inc., 426 U.S. 438, 445 (1976) (basing its holding on consideration of a reasonable investor's judgment).

139. Moreover, denying a remedy to undiversified investors creates an added incentive to diversify. One might even say that federal securities law should ignore the interests of undiversified investors just as the definition of materiality ignores the interests of stockholders who merely might be interested in the disclosure of a particular item of information. See TSC Indus., Inc., 426 U.S. at 463 (holding that an omitted fact in a proxy statement is material if there is a substantial likelihood that a reasonable investor would consider it important in deciding how to vote). One could also argue that an investor who voluntarily assumes unnecessary risk by failing to diversify when possible should be denied a remedy on grounds similar to assumption of risk in tort. But as I have argued elsewhere, such an investor might have a claim against her broker or investment adviser. See Richard 
Finally, even if one sees this conflict of investor interests as a toss-up, the potential benefits of derivative recovery tip the scales decidedly against class certification since a derivative action benefits all stockholders, eliminates feedback both as an element of damages and as a loss for holders, and leaves buyers in the same position as they would have been in the absence of fraud. ${ }^{140}$

The question remains whether a court may deny class certification solely on the ground that a class action is contrary to the interests of reasonable investors. It seems clear that if they could vote on the matter behind a veil of ignorance-not knowing whether they are buyers, sellers,

A. Booth, The Suitability Rule, Investor Diversification, and Using Spread to Measure Risk, 54 Bus. LAw. 1599, 1602 (1999) (discussing

[T] he actionability of suitability claims .... the theory and practice of diversification ... and the motivations that may lead a broker to recommend excessively risky securities and investment strategies and the various methods that may be used to quantify or compare risk, focusing in particular on how spread may be used as a surrogate for the direct measurement of risk.

). See also Richard A. Booth, Damages in Churning Cases, 20 SeC. REg. L. J. 3 (1992) (discussing measure of damages in investor disputes with brokers). This is not to say that an undiversified investor should have no remedy if she is a victim of securities fraud. Some investors are rationally undiversified. For example, it is not irrational for an investor who seeks to exercise control over the issuer through the ownership of stock to fail to diversify. But such an investor has no need for a class action. Moreover, if such an investor has a claim it is likely to be one against a counterparty to a purchase or sale and not one against the issuer.

140. As many scholars have noted, defendant companies settle in many cases that appear to have little or no merit. That phenomenon may be attributable in part to overdeterrencethe possibility that class action damages may be far in excess of the real harm to investors which itself is partly attributable to feedback. Since there is no feedback in a derivative action, the incentive to settle is undistorted and the merits should matter. See Janet Cooper Alexander, Do the Merits Matter? A Study of Settlements in Securities Class Actions, 43 StAN. L. REV. 497, 598 (1991) (arguing that we should "reconsider our faith in the propositions that settlements are as good as or better than trial, that procedural rules should favor settlement over trial, and that in civil cases any disposition to which the parties agree is ipso facto a desirable result." The abolition of securities fraud class actions might also give rise to more derivative claims in good news cases. As noted above, feedback from securities fraud class actions has the effect of magnifying the downward price change in a bad news case but muting the upward price change in a good news case. Without such muting, one would expect a bigger price jump in good news cases. But it is not clear who would sue. In other words, it is not clear that cases such as Basic would ever arise as derivative actions although it is conceivable that a stockholder might sue on the theory that stock price would have increased even further but for feedback and litigation expenses. In addition, the approach advocated here could also change how we look at scienter. Although the standard would likely be the same, the focus would almost certainly be different. Under current law, where the claim belongs to buyers, the focus is largely on whether there is a duty to disclose, whether the information is ripe for disclosure, and whether there was an illicit motive for nondisclosure. In a derivative action, the focus would likely be on whether the responsible officers knew or should have known that nondisclosure would result in an increase in the cost of equity or the cost of capital. 
or holders-diversified investors would likely vote to abolish securities fraud class actions altogether. ${ }^{141}$ Indeed, even undiversified investors might agree since they too may gain as buyers and lose as holders. Needless to say, in an ordinary non-representative action it is not up to the court to decide whether it is wise for a plaintiff to sue. But in a representative action, such as a class action or a derivative action a court has a positive duty to consider the interests of absent class members. It is quite clear that in a derivative action the court may decide whether the action is in the best interest of the corporation - the absent stockholders - and accordingly whether it should proceed or be dismissed. ${ }^{142}$ Many of the same principles apply in class actions. For example, the court must determine that the named plaintiff is an adequate representative of the class and must approve any settlement. ${ }^{143}$ Thus, a court is clearly justified in considering the macroeconomic questions raised by securities fraud class actions. ${ }^{144}$

141. See supra note 25 .

142. See A.L.I., PRINCIPLES OF CORP. GOVERNANCE $§ 7.10$ (1994) (stating the standard of review for deciding whether a derivative action should be dismissed). See also FED. R. CIV. P. 23.1(c) (stating the same rule found in the ALI's Principles of Corporate Governance sections 7.14, 7.15); Joy v. North, 692 F.2d 880, 882 (2d Cir. 1982) (refusing to grant summary judgment to the corporation on appeal of a derivative claim); Zapata Corp. v. Maldonado, 430 A.2d 779, 787-89 (Del. 1981) (holding that power of court to approve settlement implies that court has authority to review merits of corporation's decision to seek dismissal); A.L.I., Principles OF CORP. GOVERnANCE $\S \S 7.14,7.15$ (1994) (stating that a derivative action may not be settled without approval of court and court must determine that settlement balance of corporate interests warrants approval).

143. See FED. R. CiV. P. 23(a), (e).

144. The courts could dismiss most securities fraud class actions for failure to state a claim for compensable damages - and a fortiori for lack of loss causation. To be sure, the argument requires a court to focus on the net effect of the fraud. To some extent the courts do consider the net interests of the plaintiff class when (for example) they eliminate the claims of in-and-out traders in estimating damages. The tension between individual claims and net claims is also evident in the varying approaches to materiality. The Supreme Court has focused on an idealized reasonable investor in formulating the standard that a fact is material if a reasonable investor would consider it important in deciding how to act. But the court has emphasized that a fact need not be so important that it would change the investor's decision. See Basic, Inc. v. Levinson, 485 U.S. 224, 238-41 (1988) (refining the materiality standard set out in TSC Industries); TSC Indust., Inc., 426 U.S. at 463 (holding that an omitted fact is material if there is a substantial likelihood that a reasonable investor would consider it important in deciding how to vote); see also Mills v. Elec. Auto-Lite Co., 396 U.S. 375, 384-85 (1970) (discussing materially misleading information in proxy materials); Va. Bankshares, Inc. v. Sandberg, 501 U.S. 1083, 1087, 1099 (1991) (holding that conclusory statements of opinion can be materially misleading, but that the causation requirement must be met). On the other hand, it is difficult to believe that a fact could be material if does not change the decision of any investor or if it does not have some effect on the market. See Dura Pharms., Inc. v. Broudo, 544 U.S. 336, 346-48 (2005) (holding that to establish securities fraud a plaintiff must to show causal connection between misrepresentation and fraud and that artificial price inflation alone does not meet the loss causation requirement). Thus, some courts have ruled that for a fact to be material it must affect market price perceptibly. See Oran v. Stafford, 226 F.3d 275, 282 (3d Cir. 2000) 


\section{CONCLUSION}

Although securities fraud class actions are a well-established legal institution, few (if any) such actions in fact satisfy the rigorous requirements imposed by Rule 23 of the Federal Rules of Civil Procedure for certification as a class action. There invariably will be a significant number of investors in any plaintiff class who would oppose class certification because they would lose more from a successful class action than they would gain. As a result, it is impossible for anyone to be an adequate representative of the class. Moreover, it is likely that in most meritorious securities fraud actions, part of the decrease in stock price that gives rise to the claim will come from expenses associated with defending and settling the securities fraud claim and from harm to the reputation of the defendant company resulting in an increase in the cost of capital. These claims are derivative rather than direct. Accordingly, it is the corporation - and not individual buyers - that should recover. In addition, it is much more efficient for such claims to be handled as derivative actions. Thus, a derivative action is superior to a class action. That too precludes certification under Rule 23. Finally, policy considerations also militate against certification. Diversified investors are protected against securities fraud by virtue of being diversified and have no need for a remedy that effectively reduces their returns. Since the vast majority of investors are diversified (and since it is irrational for most investors not to diversify), their interests should trump those of any undiversified investors who would favor a class action remedy. Moreover, class actions constitute excessive deterrence, whereas derivative actions provide a response that is proportional to the true harm suffered by investors. In short, when faced with a motion to certify a securities fraud action as a class action, a court should ordinarily treat the action as derivative and proceed accordingly. To be clear, this approach would effectively abolish securities fraud class actions. But as demonstrated here, investors in the aggregate would be better off as a result.

(explaining that the market price must change significantly in order to meet the causation requirement). But see Matrixx Initiatives, Inc. v. Siracusano, 131 S.Ct. 1309, 1318-22 (2011) (explaining that even though adverse event reports were not statistically significant, this did not mean that the reports were not material to a reasonable investor); No. 84 Employer-Teamster Joint Council Pension Trust Fund v. Am. W. Holding Corp., 320 F.3d 920, 934 (9th Cir. 2003) (holding that "the company's optimistic statements, which failed to disclose concerns regarding the safety of a product and unlikelihood of agency of approval were material"). 


\section{APPENDIX}

\section{Class Actions \& Settlements by Year}

The following chart is derived from CORNERSTONE RESEARCH, SECURITIES Class ACtION FiLINGS: 2010 YeAR IN REVIEW 1 (2011) (for data relating to filings and disclosure dollar loss); ELLEN M. RYAN \& Laura E. Simmons, Cornerstone Research, Securities Class ACtion SetTlements, 2009 REVIEW AND ANALYSIS 1 (2009) (for data relating to settlements 2001 to 2010); and LAURA E. SIMMONS \& ELLEN M. RYAN, CORNERSTONE RESEARCH, POST-REFORM ACT SECURITIES SETTLEMENTS: 2005 REVIEW AND ANALYSIS 1 (2006) (for data relating to settlements 1996 to 2000). DDL refers to aggregate price change on the date of corrective disclosure.

\begin{tabular}{|l|r|r|r|r|r|}
\hline YEAR & FILINGS \# & FOREIGN \# & DDL \$B & SETTLE \# & SETTLE \$M \\
\hline 1996 & 111 & 6 & 14 & & \\
\hline 1997 & 174 & 6 & 42 & 14 & 150 \\
\hline 1998 & 242 & 18 & 80 & 29 & 444 \\
\hline 1999 & 209 & 10 & 140 & 65 & 1123 \\
\hline 2000 & 216 & 12 & 250 & 90 & 4701 \\
\hline 2001 & 180 & 14 & 198 & 95 & 2108 \\
\hline 2002 & 224 & 21 & 201 & 111 & 3008 \\
\hline 2003 & 192 & 16 & 77 & 94 & 2693 \\
\hline 2004 & 228 & 27 & 144 & 110 & 3626 \\
\hline 2005 & 182 & 25 & 93 & 119 & 10182 \\
\hline 2006 & 119 & 13 & 52 & 90 & 18603 \\
\hline 2007 & 177 & 29 & 158 & 108 & 7600 \\
\hline 2008 & 223 & 30 & 221 & 97 & 2798 \\
\hline 2009 & 168 & 20 & 84 & 101 & 3793 \\
\hline 2010 & 176 & 28 & 72 & 86 & 3119 \\
\hline & & & & & $\mathbf{6 3 9 4 8}$ \\
\hline TOTALS & $\mathbf{2 8 2 1}$ & $\mathbf{2 7 5}$ & $\mathbf{1 8 2 6}$ & $\mathbf{1 2 0 9}$ & \\
\hline
\end{tabular}




\section{Formulas for Calculating Feedback}

\section{BAD NEWS CASE:}

PRE-DISCLOSURE MARKET VALUE (10M shares): POST-DISCLOSURE THEORETICAL VALUE:

DAMAGES TO BUYERS ( $60 \%$ absolute turnover):

NET MARKET VALUE POST (tentative) $(\$ 90 \mathrm{M}-6 \mathrm{M})$ :

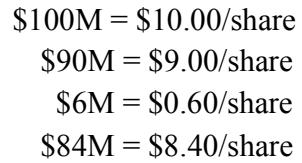

But if market value post is $\$ 84 \mathrm{M}$, then damages should be $16 \mathrm{M} \times .60=\$ 9.6 \mathrm{M}$.

Now market value post is $\$ 90 \mathrm{M}$ less $9.6 \mathrm{M}=81.4 \mathrm{M}=\$ 8.14 /$ share.

Process repeats to limit of $\$ 15 \mathrm{M}$ in total damages payable to buyers.

DAMAGES TO BUYERS:

BOTTOM LINE FOR BUYERS:

BOTTOM LINE FOR HOLDERS:

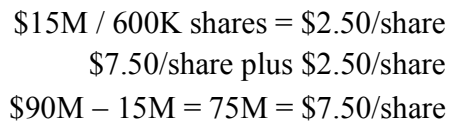

GENERAL RULE FOR BAD NEWS CASES:

total decrease in market value $=$ theoretical decrease $/(1-\%$ of shares damaged $)$

Note that the formula makes it clear that the greater the percentage of shares damaged (the greater the turnover of different shares), the greater the total decrease in market price (and the greater the aggregate damages or settlement value). Indeed, in a case in which all of the shares have turned over, the total decrease in value is theoretically infinite. To be sure, a company cannot decline in value to less than zero. But securities fraud class action damages can wipe out $100 \%$ of a company's market capitalization even though some stockholders did not trade. The following chart sets forth the results at various levels of absolute turnover.

\section{BAD NEWS CASE EXAMPLES}

Assume hypothetical pre-damages decrease of \$10M:

If $20 \%$ of shares are damaged, total award is $\$ 2.5 \mathrm{M}$ or $\$ 1.25 /$ share.

If $40 \%$ of shares are damaged, total award is $\$ 6.67 \mathrm{M}$ or $\$ 1.67 /$ share.

If $50 \%$ of shares are damaged, total award is $\$ 10 \mathrm{M}$ or $\$ 2.00 /$ share.

If $60 \%$ of shares are damaged, total award is $\$ 15 \mathrm{M}$ or $\$ 2.50 /$ share.

If $80 \%$ of shares are damaged, total award is $\$ 40 \mathrm{M}$ or $\$ 5.00 /$ share.

If $90 \%$ of shares are damaged, total award is $\$ 100 \mathrm{M}$ or $\$ 10.00 /$ share.*

* Note that $\$ 100 \mathrm{M}$ is more than entire value of company at $\$ 9$ per share. 


\section{GOOD NEWS CASE:}

PRE-DISCLOSURE MARKET VALUE (10M shares): POST-DISCLOSURE THEORETICAL VALUE: DAMAGES TO SELLERS (60\% absolute turnover): NET MARKET VALUE POST (tentative) $(110 \mathrm{M}-6 \mathrm{M})$ :
$\$ 100 \mathrm{M}=\$ 10.00 /$ share

$\$ 110 \mathrm{M}=\$ 11.00 /$ share

$\$ 6 \mathrm{M}=\$ 0.60 /$ share

$\$ 104 \mathrm{M}=\$ 10.40 /$ share

But if market value post is $\$ 104 \mathrm{M}$, then damages should be $4 \mathrm{M} \mathrm{x} .60=\$ 2.4 \mathrm{M}$.

Now market value post is $\$ 110 \mathrm{M}$ less $\$ 2.4 \mathrm{M}=107.6 \mathrm{M}=\$ 10.76 /$ share.

Process repeats to limit of $\$ 3.75 \mathrm{M}$ in total damages to sellers.

DAMAGES TO SELLERS:

BOTTOM LINE FOR SELLERS:

BOTTOM LINE FOR HOLDERS:

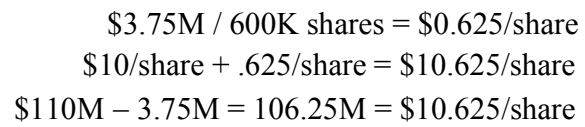

$\$ 3.75 \mathrm{M} / 600 \mathrm{~K}$ shares $=\$ 0.625 /$ share $\$ 10 /$ share $+.625 /$ share $=\$ 10.625 /$ share $\$ 110 \mathrm{M}-3.75 \mathrm{M}=106.25 \mathrm{M}=\$ 10.625 /$ share

GENERAL RULE FOR GOOD NEWS CASES:

total increase in market value $=$ theoretical increase $/(1+\%$ of shares damaged $)$

Note that the formula makes it clear that the greater the percentage of shares damaged (that is, the greater the turnover of different sharesabsolute turnover), the smaller the total increase in market price (and the smaller the aggregate damages or settlement value). The following chart sets forth the results at various levels of absolute turnover.

\section{GOOD NEWS CASE EXAMPLES}

Assume hypothetical pre-damages increase of \$10M:

If $20 \%$ of shares are damaged, total award is $\$ 1.67 \mathrm{M}$ or $\$ .833 /$ share.

If $40 \%$ of shares are damaged, total award is $\$ 2.86 \mathrm{M}$ or $\$ .714 /$ share.

If $50 \%$ of shares are damaged, total award is $\$ 3.33 \mathrm{M}$ or $\$ .667 /$ share.

If $60 \%$ of shares are damaged, total award is $\$ 3.75 \mathrm{M}$ or $\$ .625 /$ share.

If $80 \%$ of shares are damaged, total award is $\$ 4.44 \mathrm{M}$ or $\$ .556 /$ share.

If $100 \%$ of shares are damaged, total award is $\$ 5.00 \mathrm{M}$ or $\$ .500 /$ share.*

* Note that $\$ 5 \mathrm{M}$ is exactly half of the hypothetical increase. 


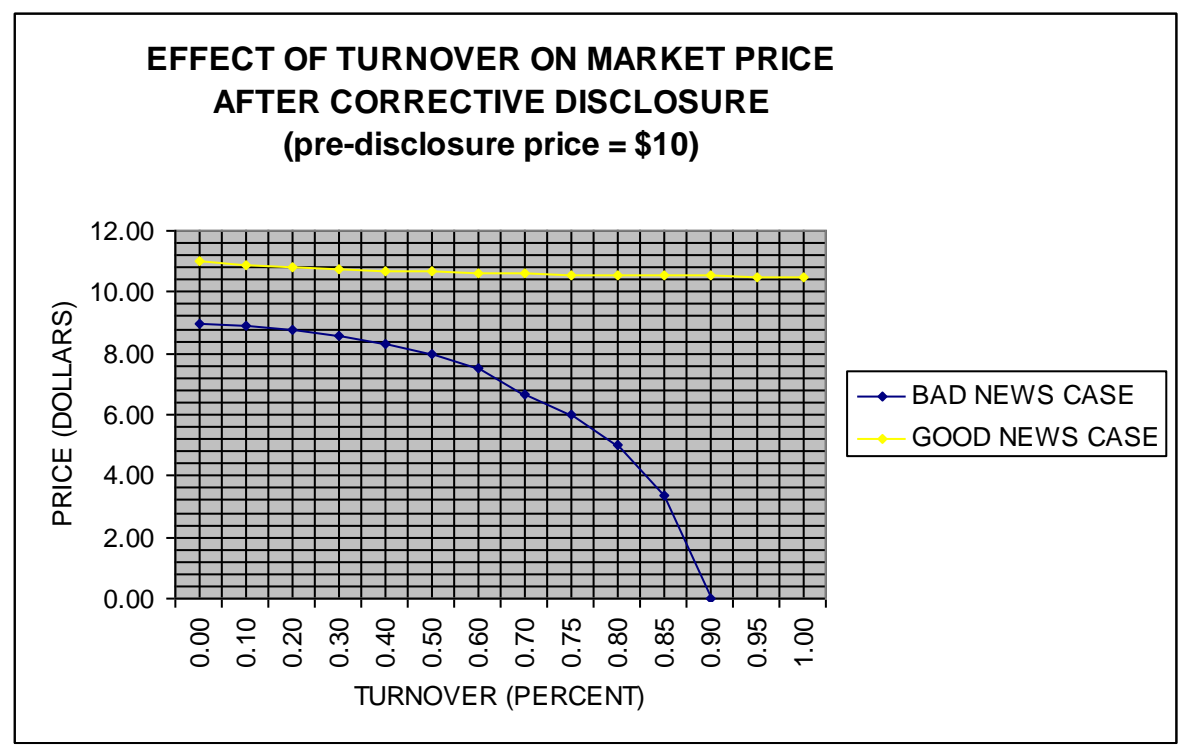

\section{A Further Note on Trading Style}

In practice, portfolio-balancers will almost always oppose securities fraud class actions. But as with all-or-nothing traders, portfolio-balancers who are both buyers and holders with regard to a fraud-affected stock may sometimes favor a class action depending on the size of the class and the number of shares bought versus the number of held. In general, as the plaintiff class gets smaller, the feedback effect is reduced, and the additional loss suffered on shares held because of the class action is offset by the recovery. For example, a $10 \%$ fundamental decrease in price becomes a $20 \%$ decrease if the plaintiff class comprises $50 \%$ of shares. But if the plaintiff class comprises just $20 \%$ of shares, a $10 \%$ decrease in price becomes a $12.5 \%$ decrease.

Thus, where the number of damaged shares is relatively small as a percentage of shares outstanding, a buyer-holder may come out ahead from a class action recovery. For example, assuming a $50 \%$ class and a $20 \%$ decline in price, an investor who held $\$ 750$ in shares and bought $\$ 1250$ in additional shares would break even (assuming full recovery less $20 \%$ in expenses). But assuming a $20 \%$ class and a $12.5 \%$ decline in price, a buyerholder would break even if he held $\$ 1500$ in shares and bought $\$ 500$ in additional shares. ${ }^{145}$

To be sure, a $20 \%$ class seems relatively small in a world in which

145. Note that the percentage decrease in price does not matter to the calculation. All that matters is the size of the class and the ratio of shares bought to shares held. 
marketwide turnover is more than $130 \%$ and class periods average about 300 days. Indeed, at a turnover rate of $130 \%$ every share of stock is bought and sold once every 280 days. That would seem to suggest that the plaintiff class should usually include $100 \%$ of the stockholders. Obviously that cannot be true. If all of the stockholders recover all of their losses, the stock price of the company will be driven to zero in every case by the feedback effect. The answer to this puzzle is that some shares are traded much more often than once a year, while other shares are seldom traded at all. For example, if a particular stock has a turnover of $100 \%$ per year, it could be that every share trades once a year or that half of the shares trade twice a year or that $20 \%$ of the shares trade five times a year. In a largely anonymous market, there is no way to know. Accordingly, there is no way to know how many shares are represented in a plaintiff class until the action is settled and claims are submitted.

On the other hand, it is rare if not unknown for a plaintiff class to recover the full loss suffered. If a class comprising $50 \%$ of outstanding shares recovers $50 \%$ of its losses, the feedback effect would be as if the class comprised $25 \%$ of outstanding shares.

Although it might seem possible that many diversified buyer-holders might increase their holdings of a given stock by as much as 33\% in any given year-from $\$ 1500$ to $\$ 2000$ as in the above example - this is really quite a large adjustment. If the additional investment is because of rebalancing, it implies that the stock in question has increased in value by $33 \%$ in excess of any increase in the value of the market as a whole. Otherwise, it implies that the investor has increased the size of his portfolio by $33 \%$ in excess of any marketwide increase in value. While it may not be unusual for an individual investor to do so, it would be quite extraordinary for a mutual fund or retirement plan to increase in aggregate size by $33 \%$ because of cash inflows in the space of a year.

As for the individual investor, it is entirely possible that the size of one's portfolio might grow by $33 \%$ in the space of a year, especially if the portfolio is small in the first place as it might be with a relatively young investor. But it is quite likely that such an investor will invest through a fund of some sort since it is difficult to achieve diversification with a small portfolio. While such an investor might favor a class action, most will have most of their claim cut off by virtue of the fact that their fund was a relatively small net buyer of the fraud-affected stock. For example, suppose that an investor with $\$ 100,000$ invested in the Rearguard Equity Fund inherits another $\$ 100,000$ and invests the entire amount in the same fund. Suppose further that Rearguard had recently increased its holdings in Enron from $4 \%$ to 5\%. Shortly thereafter, Enron stock collapses to zero. If the investor had invested directly in Enron, he would have a claim for a $\$ 5000$ loss. But his share of the fund's claim is a mere $\$ 1000$ for the newly 
invested cash (plus another $\$ 1000$ for his existing investment). ${ }^{146}$

The foregoing thus suggests yet another potential for conflicting investor interests. Up to now we have generally assumed that diversified investors buy and sell equal amounts of stock when they trade. In the aggregate, this is true by definition. But it is entirely possible that some diversified investors buy more stock than they sell and thus may lose from securities fraud more often than they win. Such investors may favor securities fraud class actions. On the other hand, for every such net saver who adds cash to her account there is another net spender who subtracts cash from his account. Presumably, such an investor will oppose securities fraud class actions.

The foregoing analysis raises a fundamental question for fund managers. How should the fund proceed when it has a claim in a class action? Should the fund always file a claim on the theory that it should collect any amounts that it can collect for the benefit of its own stockholders? Or should the fund oppose certification in cases in which it stands to lose more on its holdings of the fraud-affected stock than it stands to gain in any recovery? And should it matter that fund investors will have differing preferences? The answer to the last question seems easy. A fund cannot realistically consider the individual preferences of fund investors. Thus, it would seem that the fund should decide how to proceed based on the interests of the fund as a whole. Even though it might be argued that the fund has a fiduciary duty to its investors to serve their interests, there is more than one way to do so. The fact that individual fund investors may have conflicting interests seems to dictate that the fund should be managed with a view to the whole. The point is that in a world in which most investors invest through funds, the interests of individual investors can easily be different from the interests of the funds in which they invest. ${ }^{147}$

146. Moreover, as a practical matter, the litigation may drag on for several years before the fund recovers anything. When it does recover, the award is likely to be added back to the fund for the benefit of the investors at the time the award is received. So new investors in the fund get a windfall, while investors who have cashed out and reinvested elsewhere get bupkis. See Richard A. Booth, Who Should Recover What for Late Trading and Market Timing?, 1 J. Bus. TECH. L. 101, 101-02 (2006) (discussing the effects of late trading and abusive trading practices).

147. To be sure, there are times when in the aggregate, mutual fund cash inflows exceed outflows (and vice versa). So there will be times when the interests of funds may tend to be more consistent with those of investors who have increased (or decreased) their holdings significantly. 


\section{Effect of Class Size on Recovery}

The following charts show the effects of a class action for various combinations of stock held and stock bought assuming a stockholder who has a \$2000 investment at the time of corrective disclosure and assuming a decrease in price (in the absence of a class action) of $10 \%$ and assuming that litigation expenses equal $20 \%$ of the settlement amount (if any).

\section{PLAINTIFF CLASS COMPRISES 50\% OF OUTSTANDING SHARES}

\begin{tabular}{|l|r|r|r|r|}
\hline DOLLAR & DOLLAR & RECOVERY & ENDING & ENDING VALUE \\
VALUE OF & VALUE OF & NET OF 20\% & VALUE WITH & CLASS \\
SHARES & SHARES & EXPENSES & CLASS ACTION \\
HELD & BOUGHT & & 1600 & 1800 \\
\hline 2000 & 0 & 0 & 1680 & 1800 \\
\hline 1500 & 500 & 80 & 1760 & 1800 \\
\hline 1000 & 1000 & 160 & 1840 & 1800 \\
\hline 500 & 1500 & 240 & 1920 & 1800 \\
\hline 0 & 2000 & 320 & & \\
\hline
\end{tabular}

Note that the stockholder would favor a class action here only if she bought $\$ 1250$ or more of the stock during the fraud period. In other words, only if she increased her holdings by $62.5 \%$ or more (which is unlikely for a portfolio balancing investor).

If the plaintiff class comprises $20 \%$ of the outstanding shares (rather than $50 \%$ ), the feedback effect is smaller. The price of the stock will fall by $12.5 \%$ as a result of feedback (rather than by $20 \%$ as in the previous example). The following chart shows the effects of a class action under these circumstances. 


\section{PLAINTIFF CLASS COMPRISES 20\% OF OUTSTANDING SHARES}

\begin{tabular}{|l|r|r|r|r|}
\hline DOLLAR & DOLLAR & RECOVERY & ENDING & ENDING VALUE \\
VALUE OF & VALUE OF & NET OF 20\% \\
SHARES & SHARES & EXPENSES & VALUE WITH \\
HELD & CLASS & CLASS ACTION \\
\hline 2000 & 0 & 0 & 1750 & 1800 \\
\hline 1500 & 500 & 50 & 1800 & 1800 \\
\hline 1000 & 1000 & 100 & 1850 & 1800 \\
\hline 500 & 1500 & 150 & 1900 & 1800 \\
\hline 0 & 2000 & 200 & 1950 & 1800 \\
\hline
\end{tabular}

In this case, an investor will favor prosecution of the class action if he bought more than $\$ 500$ of the stock. In general, as the plaintiff class gets smaller, the feedback effect is reduced, and the conflict between buyerholders and other class members is muted. 